\title{
THE DOHA ROUND'S PUBLIC HEALTH LEGACY: STRATEGIES FOR THE PRODUCTION AND DIFFUSION OF PATENTED MEDICINES UNDER THE AMENDED TRIPS PROVISIONS ${ }^{\dagger}$
}

\author{
Frederick M. Abbott* and ferome H. Reichman ${ }^{\star \star}$
}

\section{ABSTRACT}

The entry into force of the World Trade Organization (WTO) TRIPS Agreement in 1995 transformed the international intellectual property system. The harmonization of basic intellectual property standards has operated to protect investment in innovation, limiting risks from unjustified 'free riding'. Yet these same harmonized IP standards sharply curtailed the traditional capacity of suppliers of public goods, such as health care and nutrition, to address priority needs of less affluent members of society, particularly in (but not limited to) developing countries. In the Doha Declaration, the Waiver Decision of 30 August 2003 and the Article 31 bis Protocol of Amendment, stakeholders concerned with re-opening policy space for the supply of newer pharmaceutical products pushed back against restrictive elements of the TRIPS Agreement.

Governments around the world are in the process of deciding whether to ratify and accept the Article 31 bis Amendment. Based on their Study for the International Trade Committee of the European Parliament, the authors argue that acceptance of the Amendment will provide a 'net benefit' for countries seeking to improve access to medicines. At the insistence of WTO delegations acting on behalf of the originator pharmaceutical industry lobby, Article 31 bis regrettably is saddled with unnecessary administrative hurdles. Nonetheless, through skillful lawyering, political determination and coordinated planning, the system can be made to work. Among other options, expeditious back-to-back compulsory licensing linked with pooled

$\dagger$ This article is based on a study requested by the European Parliament's Committee on International Trade and commissioned by the Directorate-General for External Policies of the Union, June 2007, see below n 43, and it is used here with the latter's permission.

* Edward Ball Eminent Scholar Professor of International Law, Florida State University College of Law, Member of the Board of Editors. E-mail: fabbott@law.fsu.edu.

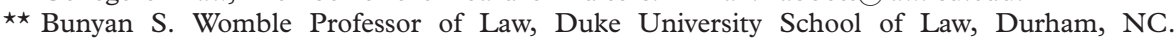
Member of the Board of Editors. 
procurement strategies may effectively achieve economies of scale in production and distribution of medicines.

The authors doubt that the international political environment would support renegotiation of an 'improved' solution. They express concern that failure to bring the Amendment into force will open the door to a campaign to undermine the Waiver Decision. Recent events in Brazil and Thailand illustrate both the opportunities and risks associated with implementing TRIPS exception mechanisms, and help to inform views on the negotiating environment. Specific proposals for regional cooperation in implementing the Amendment are laid out, and the authors emphasize the importance of pursuing concrete transfer of technology measures in support of developing country pharmaceutical manufacturing. Over-reliance on private market mechanisms for the supply of public health goods leaves the international community with an unresolved collective action problem on a large scale.

Table of Contents

I. INTRODUCTION

A. Adverse Impact of the TRIPS Agreement on the Provision of Public Goods.

B. Impact of the TRIPS Agreement on Access to Medicines in Developing Countries

1. End of the Transitional Periods ...............................................928

2. The New Compulsory Licensing Scheme …...............................929

3. The Ratification Process ........................................................930

II. THE EVOLVING LEGAL INFRASTRUCTURE .............................932

A. India and the Problem of Exports under Article 31(f) ....................934

B. Terms of the WTO Measures …………………....................................936

1. Scope of Covered Diseases .........................................................936

2. General Notification and Eligible Importing Countries..................937

3. Determination as to Insufficient or No Capacity..........................939

4. Licensing and Conditions........................................................ 940

(a) Importing Members.......................................................................940

(b) Exporting Members................................................................9942

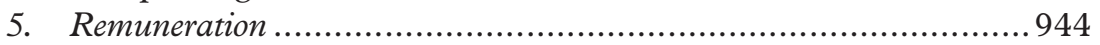

6. Measures to Prevent Diversion and Non-authorized Importation ...944

7. Special Regional Treatment ...................................................... 944

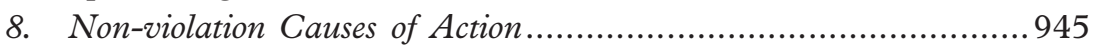

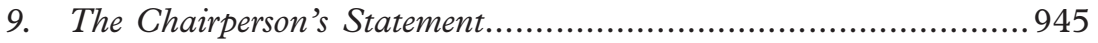

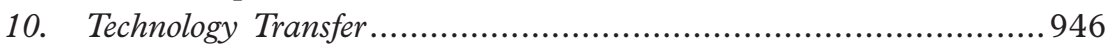

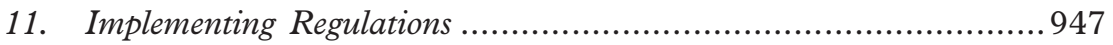

12. Tentative Evaluation of the Pending Enactments......................... 947

C. The Grants of Compulsory Licenses in Brazil and Thailand ........949

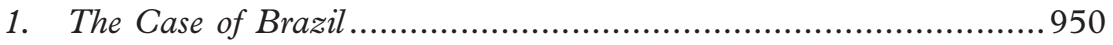




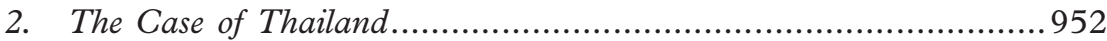

3. Foreign Reaction............................................................... 953

4. Concluding Observations .................................................. 956

D. The Untested Alternative Route under Article 30 .........................957

E. Multilateral Negotiations on a Substantive Patent Law Treaty (SPLT) ........................................................................................... 958

F. The problem of the Free Trade Agreements .................................... 962

1. Agreements of the United States.......................................... 962

2. Agreements of the European Union ........................................965

G. The World Health Organization's Intergovernmental

Working Group on Public Health, Innovation and Intellectual Property (IGWG) ................................................. 967

III. MAKING THE AMENDMENT SYSTEM WORK ......................969

A. Goals and Limits of Compulsory Licensing ..................................970

B. The High Transaction Costs of Single State Action .........................972

C. The Potential Benefits of Pooled Procurement Strategies...............973

1. A Large Regional Model With Many LDCs.............................. 974

2. A Smaller Model With or Without LDCs................................. 976

3. Fulfilling Technology Transfer Obligations under Article 66.2 .........977 97

4. Technical Cooperation between Developing Countries.................... 977

D. The Overriding Importance of Stimulating Local Production ......977

E. Obstacles to Obtaining Key Active Ingredients (APIs) ...................979

F. Countervailing Pressures by Industry and Governments ............... 980

G. New Patent Incentives and Old Market Failures............................ 981

1. Stimulating Private RED Investment in Poverty-related, Tropical or Neglected Diseases .......................................................... 981

2. Changing the Marketing Model ............................................... 982

3. The Continuing Role of Public-Private Partnerships ..................... 983

4. Strengthening the Global Scientific Foundation............................. 983

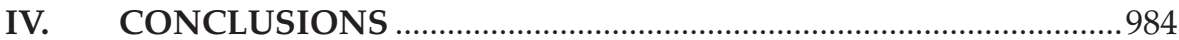

\section{INTRODUCTION}

By harmonizing minimum levels of protection in the territories of some 150 World Trade Organization (WTO) Members, the TRIPS Agreement's provisions on patents, copyrights and other forms of intellectual property aimed to improve the overall framework conditions for the transfer of knowledge and technology in a global marketplace. ${ }^{1}$ One primary goal of this Agreement was

\footnotetext{
${ }^{1}$ Agreement on Trade-Related Aspects of Intellectual Property Rights, Marrakesh Agreement Establishing the World Trade Organization, Annex 1C, 15 April 1994, in World Trade Organization, The Legal Texts: The Results of The Uruguay Round of Multilateral Trade Negotiations 321 (1999) [hereinafter TRIPS Agreement], available at http:/www.wto.org. See generally, UNCTAD-ICTSD Resource Book on TRIPS and Development, (Cambridge University Press 2005), available at http://www.iprsonline.org.
} 
to prohibit Member governments from allowing unbridled free-riding on foreign creations and innovations under the limiting assumptions of territoriality, ${ }^{2}$ which subject exporters of knowledge goods to the vagaries of national treatment in the absence of countervailing treaties. ${ }^{3} \mathrm{~A}$ second major goal was to secure to inventors and creators a return on their investments from the sale or licensing of innovative knowledge goods anywhere within the supranational market for goods and services regulated by the TRIPS Agreement. ${ }^{4}$

There is growing evidence that this component of the Agreement Establishing the WTO of $1994^{5}$ has fulfilled these goals by substantially elevating the returns (or 'rents') to technology-exporting countries in the period since its adoption. ${ }^{6}$ An 'incipient transnational system of innovation' emerging from the TRIPS Agreement ${ }^{7}$ has likewise created incentives and opportunities for entrepreneurs even in developing countries who are or become capable of producing and exporting knowledge goods to an increasingly competitive global market. ${ }^{8}$

At the same time, the TRIPS Agreement-increasingly supplemented by an array of TRIPS-plus intellectual property norms adopted in posterior multilateral, regional and bilateral agreements ${ }^{9}$ - has greatly complicated the work of government ministries in developing countries at all levels of the per

${ }^{2}$ Frederick M. Abbott, 'Protecting First World Assets in the Third World: Intellectual Property Negotiations in the GATT Multilateral Framework', 22 Vand J Transnat'l L 689 (1989) and Jerome H. Reichman, 'From Free Riders to Fair Followers: Global Competition Under the TRIPS Agreement' 29 NYU J. Int'l L. Pol. 11 (1996).

${ }^{3}$ See Paris Convention for the Protection of Industrial Property (1883), as last amended 1967, Article 2(1); Microsoft Corp. v ATE T Corp., 127 S. Ct. 1746 (2007); ITC Limited v Punchgini, Inc., 482 F.3d 135 (2d Cir. 2007) (holding that US trademark law remains territorial and cannot provide internationally required protection of famous marks under the TRIPS Agreement until Congress adopts implementing legislation).

${ }^{4}$ Keith E. Maskus, 'Intellectual Property Rights In the Global Economy' (IIE 2002); Jane Ginsburg, Toward Supranational Copyright Law? The WTO Panel Decision and the "Three Step Test" for Copyright Exceptions, 187 Revue Internationale du Droit d'Auteur 3, 2001. See also Rochelle Cooper Dreyfus and Andreas L. Lowenfeld, 'Two Achievements of the Uruguay Round: Putting TRIPS and Dispute Settlement Together', 37 Va J Int'l L 275 (1997).

${ }^{5}$ See above $\mathrm{n} 1$.

${ }^{6}$ See e.g. Frederick M. Abbott, 'Toward a New Era of Objective Assessment in the Field of TRIPS and Variable Geometry for the Preservation of Multilateralism', 8 J Int'l Econ L 77 (2005), and references cited at n 13.

${ }^{7}$ Keith E. Maskus and Jerome H. Reichman, 'The Globalization of Private Knowledge Goods and the Privatization of Global Public Goods', in K.E. Maskus and J.H. Reichman (eds), International Public Goods and Transfer of Technology Under a Globalized Intellectual Property Regime 3-45 (Cambridge University Press 2005) [hereinafter 'IP and International Public Goods'].

${ }^{8}$ See e.g. Joseph Straus, 'The Impact of the New World Order on Economic Development: The Role of Intellectual Property Rights Systems', 6 J Marshall Rev Intell Prop 1 (2006); Keith E. Maskus, Kamal Saggi and Thitima Puttitanum, 'Patent Rights and International Technology Transfer', in IP and International Public Goods, above n 7, 265-81.

${ }^{9}$ At the multilateral level, see e.g. WIPO Copyright Treaty (1996); WIPO Performers and Phonogram Producers Treaty (1996), available at $<$ http://www.wipo.int $>$. See also negotiations

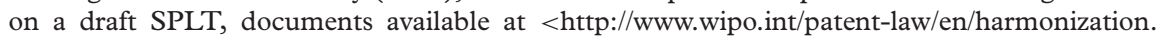
htm >; John Barton et al., Views on the Future of the Intellectual Property System, UNCTAD-ICTSD 
capita GDP spectrum. ${ }^{10}$ Both the private and public sectors in these countries must now reconcile their technology catch-up policies and strategies with higher levels of intellectual property protection than developed countries had in the past faced at comparable stages in their own economic development trajectories. ${ }^{11}$ Although these obstacles significantly increase the costs of economic development, one can arguably rationalize them as part of a bargained-for exchange that allowed developing country exporters of more traditional goods a greater access to markets in OECD countries. ${ }^{12}$

\section{A. Adverse impact of the TRIPS Agreement on the provision of public goods}

Less obvious, and often more insidious, are the difficulties and social costs that higher intellectual property standards under TRIPS and later FTAs have created for developing country governments' abilities to maintain the supply of such basic public goods as nutrition and agriculture, education, public health, environmental safety, scientific research and industrial policy (including the maintenance of a competitive rather than a command economy, where so desired). ${ }^{13}$ While these countries have unquestionably benefited from a shift to more open markets in the past two decades, their traditional responsibilities for the provision of essential public goodsalready limited by a lack of resources and the relative poverty of their citizenries - has been further hampered by the adverse exercise of private rights in technical inputs and in other indispensable knowledge goods that were formerly unprotected, or in the public domain, or otherwise available at lower, more competitive prices. ${ }^{14}$

In retrospect, a glaring defect of the multilateral trade negotiations that produced the TRIPS Agreement was the extent to which a powerful coalition of private technology exporters controlled the agenda, with few counterbalancing inputs from representatives of users, consumers, small and medium-sized entrepreneurs or-most crucial for present

Selected Issue Briefs No. 1 (April 2007), available at http://www.iprsonline.org, and; further discussion below nn 187-211 text, regarding regional and bilateral FTAs.

10 Carsten Fink and Patrick Reichenmiller, 'Tightening TRIPS: The Intellectual Property Provisions of Recent US Free Trade Agreements' (World Bank Trade Note No. 20, 2005).

${ }^{11}$ See e.g. Margaret Chon, 'Intellectual Property and the Development Divide', 27 Cardozo L Rev 2821 (2006); Ruth Okediji, 'Public Welfare and the Role of the WTO: Reconsidering the TRIPS Agreement', 17 Emory Int'l L Rev 819 (2003, Peter K. Yu et al., 'China and the WTO: Progress, Perils, and Prospects', 17 Colum J Asian L 1 (2003).

${ }^{12}$ See discussion of Uruguay Round reciprocal bargain assumptions in Abbott, 'Protecting First World Assets', above n 2.

${ }^{13}$ Maskus and Reichman, 'The Globalization of Private Knowledge Goods', above $\mathrm{n}$ 7. See also, Joseph Stiglitz, Knowledge as a Global Public Good (1998), available at http:// www.worldbank.org/knowledge/chiefecon/articles/undpk2/index.htm; Peter Drahos, 'The Regulation of Public Goods', in IP and International Public Goods, above n 7, 46-64.

${ }^{14}$ See generally IP and International Public Goods, above n 7. 
purposes-advocates representing the needs of the public sector as such. ${ }^{15}$ The dialectic between public and private interests that typically accompanies domestic intellectual property legislation in developed countries was thus sacrificed in international trade forums to a system of 'traded benefits' in other goods and services - influenced by the General Agreement on Tariffs and Trade's (GATT's) tradition and procedures ${ }^{16}$-which operated outside the customary intellectual property universe of discourse and was often deliberately indifferent to its values and methods. ${ }^{17}$

What began as a coordinated effort to improve a rudimentary worldwide intellectual property system, with particular regard to patents, thus ended with a push to ever higher levels of protection favoring the owners of existing innovation, with little regard for the needs of future innovators or the general public interest in access to knowledge and free competition. ${ }^{18}$ On the contrary, long-established balancing mechanisms (including, in certain instances, even those in the developed countries ${ }^{19}$ ) have been overwhelmed and held captive by a proliferation of international intellectual property standards that the momentum behind the TRIPS process continues to generate in multilateral, regional and bilateral arrangements. ${ }^{20}$

Nowhere have these tensions been more acute than in the pharmaceutical sector. $^{21}$ And in no other sector has the countervailing push by adversely

${ }^{15}$ See e.g. Susan K. Sell, Private Power, Public Law: The Globalization of Intellectual Property Rights (Cambridge: 2003); Christopher May and Susan K. Sell, Intellectual Property: A Critical History (Lynne Rienner: 2005); Peter Drahos and John Braithwaite, Information Feudalism: Who Owns the Knowledge Economy (Earthscan 2002).

${ }^{16}$ General Agreement on Tariffs and Trade (1994) and (1947), available at http://www.wto.org. See generally, John H. Jackson, World Trade and the Law of GATT (Bobbs-Merrill 1969) and John H. Jackson, The Furisprudence of GATT and the WTO: Insights on Treaty Law and Economic Relations (Cambridge 2000).

${ }^{17}$ See e.g. Peter Gerhart, 'Distributive Values and Institutional Design in the Provision of Public Goods', in IP and International Public Goods, above n 7, 69-77.

${ }^{18}$ See e.g. Rochelle C. Dreyfus, 'TRIPS-Round II: Should Users Strike Back?', 71 U Chi L R 21 (2004); Graeme B. Dinwoodie and Rochelle Cooper Dreyfuss, 'WTO Dispute Resolution and the Preservation of the Public Domain of Science under International Law', in IP and International Public Goods, above n 7, 861-83; Gregory Shaffer, 'Recognizing Public Goods in WTO Dispute Settlement: Who Participates, Who Decides? The Case of TRIPS and Pharmaceutical Patents Protection', in IP and International Public Goods, above n 7, 884-908.

19 See e.g. Digital Millennium Copyright Act 17 USC 1201 et seq., and European Parliament and Council Directive on the Harmonization of Certain Aspects of Copyright and Related Rights in the Information Society, Directive 2001/29/EC, O.J. 2001 No. L 167. See generally, Jerome H. Reichman, Graeme Dinwoodie and Pamela Samuelson, 'A Reverse Notice and Takedown Regime to Enable Public Interest Uses of Technically Protected Copyrighted Works', 22 Berkeley J Law and Tech (forthcoming 2007).

${ }^{20}$ See above $\mathrm{n} 9$ and below nn 187-211 and accompanying text. However, these pressures have begun to elicit increasingly stronger countervailing reactions. See e.g. WIPO Development Agenda, below n 174. See also Jerome H. Reichman and Rochelle Cooper Dreyfuss, 'Harmonization without Consensus: Critical Reflections on Drafting a Substantive Patent Law Treaty', 57 Duke L J 85 (2007); CPTech proposed Treaty on Access to Knowledge, draft of 9 May 2005, available at http://www.cptech.org/a2k/a2k_treaty_may9.pdf.

${ }^{21}$ See e.g. Frederick M. Abbott, 'Managing the Hydra: The Herculean Task of Ensuring Access to Essential Medicines', in IP and International Public Goods, above n 7 and 
affected stakeholders succeeded in re-establishing a new but still untested equilibrium between public and private interests.

\section{B. Impact of the TRIPS Agreement on access to medicines in developing countries}

Before the TRIPS Agreement of 1994 entered into force, developing country governments retained relatively unrestricted power to regulate public health, with little interference from international intellectual property law. Although the decolonization process saddled many (if not most) developing countries with membership in the Paris Convention for the Protection of Industrial Property of $1883,{ }^{22}$ the provisions of that Agreement concerning patented inventions dealt mainly with rules of priority and national treatment. ${ }^{23}$ It otherwise left states free to devise and implement their own patent systems and, as many chose to do, even to deny any patent protection for pharmaceutical products at all. ${ }^{24}$

In this environment, the ability of developing and least-developed countries (LDCs) to obtain essential medicines varied with respect to their procurement methods, local production capabilities, public health policies and general financial resources. The chief limitations on supply were not of a formal legal character, except insofar as the prevailing conditions of legal uncertainty affecting knowledge and technology transfer generally may have inhibited investment in or the diffusion of medicines benefiting Third World countries. $^{25}$

The key factors rather depended on the reverse engineering capacities of generic suppliers and their pricing policies; on the availability of key active

Frederick M. Abbott, TRIPS II, Asia and the Mercantile Pharmaceutical War: Implications for Innovation and Access, Stanford Center for International Development, Working Paper No. 308 (December 2006).

${ }^{22}$ See above $\mathrm{n}$ 3. For historical background and information on operation of the Paris Convention, see F. Abbott, T. Cottier and F. Gurry, International Intellectual Property in an Integrated World Economy 161-77 (Aspen 2007).

${ }^{23}$ E.g. Paris Convention, above n 3, Articles 2(1) and 4 bis.

${ }^{24}$ E.g. Switzerland and Italy did not provide patent protection for pharmaceutical products until 1977 and 1978, respectively. Fabio Pammolli, Laura Magazzini and Luigi Orsenigo, 'The Intensity of Competition after Patent Expiry in Pharmaceuticals: A Cross-Country Analysis', 99 Rev d'Econ Indus (2002), http://rei.revues.org/document11.html. India did not provide pharmaceutical product patent protection until 2005.

25 See e.g. Maskus, Intellectual Property Rights in the Global Economy, above n 4 (stressing positive impact of TRIPS norms on the availability of high-tech products for acquisition by developing countries, apart from licensing opportunities as such); Keith E. Maskus, Transfer of Technology and Technological Capacity Building, ICTSD-UNCTAD Dialogue, 2nd Bellagio Series on Development and Intellectual Property, 18-21 September 03, available at $<$ http:// www.iprsonline.org/unctadictsd/bellagio/docs/Maskus_Bellagio2.pdf $>$. See also, Alan O. Sykes, 'Public Health and International Law: TRIPS, Pharmaceuticals, Developing Countries, and the Doha "Solution"' 3 Chi J Int'l 147 (2002) (addressing need for international incentives in risky pharmaceutical sector). 
pharmaceutical ingredients (APIs) on the world market; on the pricing policies of the big pharmaceutical companies (and any countervailing local regulatory framework); and on the well-known failure of the research-based pharmaceutical industries in the Organisation for Economic Cooperation and Development (OECD) countries to invest in R\&D directed at diseases that primarily afflicted the poorer countries. The growing ability of some middle-income developing countries to produce low-cost generic medicines under these regimes-notably in Argentina, Brazil, Chile, India, Thailand, Egypt, Indonesia, Taiwan and South Korea-made it increasingly possible for even poor states to obtain certain low-cost generic medicines on the world market, whether such products were on or off patents. ${ }^{26}$

\section{End of the transitional periods}

Once the TRIPS Agreement of 1994 took effect, however, and its limited transitional periods expired in 2005, this situation changed radically. All developing countries (but not the LDCs) became liable to adopt and enforce all the TRIPS patent standards, and these standards necessarily applied to medicines in all WTO member countries (except LDCs) from 2005 onwards. ${ }^{27}$ With the passage of time (and the opening of 'mail boxes' holding pharmaceutical patent applications during the transitional periods), ${ }^{28}$ more and more essential medicines (for example, the so-called second- and third-line HIV drugs) will be on patent in all countries capable of supplying them to the world market, ${ }^{29}$ at least until the relevant patents expire in those countries. ${ }^{30}$

The availability of these drugs will thus depend on the pricing strategies of patent holders and on the countervailing regulatory measures states may adopt to influence them. Moreover, further efforts to tighten international intellectual property standards continue today under the Substantive Patent Law Treaty (SPLT) negotiations ongoing at the World Intellectual Property Organization (WIPO), ${ }^{31}$ and especially under Free Trade Agreements and Bilateral Trade Agreements, which adversely affect ministries of health.

26 See Abbott, TRIPS II, above n 21.

27 See Frederick M. Abbott, 'The WTO Medicines Decision: World Pharmaceutical Trade and the Protection of Public Health', 99 Am J Int'l L 317, 320-24 (2004) [hereinafter 'Abbott, WTO Medicines Decision'].

${ }^{28}$ Ibid and Janice M. Mueller, The Tiger Awakens: The Tumultuous Transformation of India's Patent System and the Rise of Indian Pharmaceutical Innovation (August 2006). University of Pittsburgh School of Law Working Paper Series. Working Paper 43, at http://law.bepress.com/ pittlwps/papers/art43.

29 See e.g. MSF Access to Medicines Campaign, The Second-Line AIDS Crisis: Condemned to Repeat?, 11 April 2007, at < http://www.doctorswithoutborders.org/news/access/thailand_ briefingdoc_04-11-2007.cfm $>$.

30 Although many blockbuster patents in the United States will soon expire, this does not directly affect the status of such patents abroad. See Paris Convention, above n 3, Article 4 bis (2).

31 See discussion of draft Substantive Law Patent Treaty (SPLT), below text accompanying nn 172-83. 
These ministries have little influence on intellectual property-related negotiations, conducted between trade negotiators, and they often remain powerless to modify or block problematic demands in response to 'take it or leave it' tactics. ${ }^{32}$

Meanwhile, the prospective social costs of further limiting poor countries' access to generic medicines after the TRIPS transition periods expired precipitated a growing crisis-largely focused on the AIDS pandemic - that might eventually have threatened the stability of the WTO itself. In a responsive effort to bolster the vertical powers of poor countries to maintain the supply of essential medicines as part of their public health responsibilities, despite elevated international intellectual property standards, the WTO Ministerial Conference adopted the Doha Declaration on the TRIPS Agreement and Public Health in November 2001. ${ }^{33}$

\section{The new compulsory licensing scheme}

This Declaration reconfirmed many of the so-called flexibilities built into the TRIPS Agreement, including the right of Members to issue compulsory licenses on public-interest grounds. ${ }^{34}$ The Declaration then provided the mandate for amplifying existing flexibilities by establishing legal machinery to enable countries lacking the capacity to manufacture generic substitutes for costly patented medicines under domestically issued compulsory licenses to obtain imports from countries able and willing to assist them without intererence from the relevant patent holders. ${ }^{35}$ This solution, which also improved the export opportunities for the generic pharmaceutical sectors in emerging economies, such as Brazil, China and India, was initially embodied in a waiver known as the Decision of 30 August $2003 .^{36}$ It would be rendered permanent in the form of an Amendment to the TRIPS Agreement, known as Article 31 bis, whose ratification is currently under consideration by many governments. ${ }^{37}$

${ }^{32}$ See e.g. Frederick M. Abbott, The Doha Declaration on the TRIPS Agreement and Public Health and the Contradictory Trend in Bilateral and Regional Free Trade Agreements, Quaker United Nations Office (Geneva), Occasional Paper No. 14, April 2004 and Frederick M. Abbott, Trade Diplomacy, the Rule of Law and the Problem of Asymmetric Risks in TRIPS, Quaker United Nations Office (Geneva), Occasional Paper No. 13, September 2003.

33 Declaration on the TRIPS Agreement and Public Health (14 November 2001), Doc. WT/ MIN(01)/DEC/2 (20 November 2001) [hereinafter Doha Declaration].

${ }^{34}$ Ibid, para 5(b). See Jerome H. Reichman with Catherine Hasenzahl, Nonvoluntary Licensing of Patented Inventions, ICTSD/UNCTAD Issue Paper No. 5 (2003); Frederick M. Abbott, 'The Doha Declaration on the TRIPS Agreement and Public Health: Lighting a Dark Corner at the WTO', 5 J Int'l Econ L 469 (2002).

${ }^{35}$ For the foundational authority, see Doha Declaration on Public Health, above n 33, para 6, and discussion in Abbott, 'WTO Medicines Decision', above n 27.

${ }^{36}$ Implementation of Paragraph 6 of the Doha Declaration on the TRIPS Agreement and Public Health (30 August 2003), Doc. WT/L/540 (1 September 2003) [hereinafter 'Waiver Decision'].

37 WTO General Council Decision of 6 December 2005, Amendment of the TRIPS Agreement, WT/L/641, 8 Dec. 2005, with attachment 'Protocol Amending the TRIPS Agreement' (with Annex setting out Article 31bis) [hereinafter 'Protocol of Amendment' or 'Amendment']. 
How the developing countries adapt this and other TRIPS flexibilities to the needs of their national and regional systems of innovation will ultimately determine both the direction of future $\mathrm{R} \& \mathrm{D}$ in the global pharmaceutical sector and the extent to which all WTO Members, and especially the developing countries and LDCs, will be able to provide essential medicines at affordable prices under their domestic public health programs. In this calculus, the potential role of the proposed Article 31 bis Amendment to shift the pharmaceutical companies pricing strategies from a 'low volume, high margin' approach to a 'high volume, low margin' approach is of primary importance. ${ }^{38}$

However, the attainment of these objectives remains largely dependent on the willingness of both importing and exporting countries not only to ratify the permanent amendment, but also to enact enabling domestic legislation, such as the European Regulation. ${ }^{39}$ Ultimate success also depends on the willingness of participating countries to adopt ancillary policies and strategies favoring cooperation rather than conflict among the various stakeholders, and on the willingness of the private generic industry to invest in the production and distribution of needed medicines at affordable prices under the amended TRIPS provisions.

\section{The ratification process}

The complexities involved in organizing and coordinating cooperative ventures along these lines have recently been highlighted in the course of the European Parliament's ongoing deliberations concerning ratification of the Amended TRIPS provisions. ${ }^{40}$ Because the pending Amendment has elicited considerable criticism from NGOs and others, ${ }^{41}$ the Parliament's International Trade Committee commissioned an in-depth analysis of the

Article 31 bis incorporates an "Annex to the TRIPS Agreement". Further references to "Annex" herein are to this "Annex to the TRIPS Agreement" incorporated by Article 31 bis.

${ }^{38}$ See Ministry of Public Health and National Health Security Office, Thailand, Facts and Evidence on the 10 Burning Issues Related to the Government Use of Patents on Three Patented Essential Drugs in Thailand, February 2007, ISBN 978-974-94591-5-7 [hereinafter the 'Thai White Paper'].

${ }^{39}$ Regulation of the European Parliament and of the Council on compulsory licensing of patents relating to the manufacture of pharmaceutical products for export to countries with public health problems, 2004/0258 (COD), PE-CONS 3674/05, Brussels, 12 April 2006.

40 Developments are reported on the website of the European Parliament. The debates and Resolution adopted by the Parliament in July 2007 pertaining to the ratification process are available at http://www.europarl.europa.eu/sides/getDoc.do?pubRef=-//EP//TEXT+TA+P6TA-2007-0353+0+DOC+XML+V0//EN\&language $=\mathrm{EN}$.

${ }^{41}$ See e.g. MSF Access to Medicines Campaign, Doha Derailed, A Progress Report on TRIPS and Access to Medicines, 27 August 2003 and Neither Expeditious, Nor A Solution: The WTO August 30th Decision Is Unworkable: An illustration through Canada's fean Chrétien Pledge to Africa, Prepared for the XVI International AIDS Conference, Toronto, August 2006, and Oxfam International, Patents versus Patients, Five years after the Doha Declaration, Oxfam Briefing Paper 95, November 2006. 
system envisioned by the Amendment and the prospects for its successful implementation. In particular, the Committee sought advice not only on the specific question of ratifying the Amendment as drafted, or not, but also on ways and means of ensuring its successful implementation, with a view to formulating an agreed policy framework with the European Commission, which will have primary responsibility for that task. ${ }^{42}$

The authors of this article were invited to write that Study, ${ }^{43}$ and many of our recommendations have been endorsed provisionally in a resolution of the European Parliament, which has deferred actual ratification pending further negotiations with the European Commission. ${ }^{44}$ The outcome of these deliberations will necessarily influence the way many other countries-both developed and developing - address the ratification issue once the European Parliament commits the Community to pursuing the goals embodied in the Amendment and in the larger policy framework of the Doha Declaration on TRIPS and Public Health. ${ }^{45}$

The purpose of this article is accordingly to review and analyze the proposed Amendment in its historical context and to translate the findings of our Study for the European Parliament into a broader set of policy considerations and recommendations. We hope that it will assist all policymakers and stakeholders likely to be involved in the coming struggle to reconcile incentives to innovate in the worldwide pharmaceutical sector with access to those same innovative products under the new legal framework established by the Amendment.

In what follows, we will first briefly depict the evolving legal infrastructure affecting the supply of pharmaceuticals to developing countries, in which the Protocol of Amendment concerning Article 31 bis is a major component. We shall then evaluate the prospects for implementing the amended flexibilities

42 Directorate-General for External Policies of the Union, Specifications, No. EXPO/B/INTA/ 2007/14.

${ }^{43}$ Frederick M. Abbott and Jerome H. Reichman, Study, Access to Essential Medicines: Lessons Learned Since the Doha Declaration on the TRIPS Agreement and Public Health, and Policy Options for the European Union, Directorate General External Policies of the European Union, EXPO/B/INTA/2007/14 June 2007 PE 381.392 (prepared for the International Trade Committee, European Parliament) [hereinafter 'Abbott and Reichman, Study'].

${ }^{44}$ European Parliament resolution of 12 July 2007 on the TRIPS Agreement and access to medicines, P6_TA-PROV(2007)0353, available at $<$ http://www.europarl.europa.eu/sides/ getDoc.do? Type=TA\&Reference=P6-TA-2007->. See also David Cronin, Parliament Delays WTO IP Health Deal Till EU Boosts Bilateral Drug Access, IP-Watch, 12 July 2007.

45 On October 24, 2007, the European Parliament gave its assent to acceptance by the European Community of the Protocol of Amendment. See European Parliament legislative resolution of 24 October 2007 on the proposal for a Council decision on the acceptance, on behalf of the European Community, of the Protocol amending the TRIPS Agreement, done at Geneva on 6 December 2005 (8934/2006-C6-0359/2006-2006/0060(AVC), P6_TA(2007) 0459. This was preceded by the reading of a Statement by the Council reflecting certain key understandings (text in authors' files). 
with some hope of success, and we shall also consider certain alternative or complementary strategies. Finally, we draw conclusions and make recommendations concerning these and other related issues, which governments inclined to ratify the Amendment may wish to consider.

\section{THE EVOLVING LEGAL INFRASTRUCTURE}

Governments around the world are currently considering ${ }^{46}$ whether to ratify and accept the Amendment to the TRIPS Agreement adopted by WTO Members on 6 December 2005, which would formally add a new Article 31bis to that Agreement. ${ }^{47}$ Proposed Article 31 bis reflects the terms of the WTO Decision of 30 August 2003 (hereinafter the 'Waiver Decision'). ${ }^{48}$ It established a waiver of certain obligations under the TRIPS Agreement for the purpose of permitting exports of patented medicines under government use and other compulsory licenses that might otherwise be prevented by the terms of the TRIPS Agreement as it entered into force on 1 January $1995 .{ }^{49}$

The Waiver Decision and Amendment have been criticized for imposing unnecessary obstacles to the effective use of compulsory licensing by countries with inadequate production capacity, ${ }^{50}$ and indeed they are not the optimal solution for stakeholders seeking the most administratively simple or expeditious mechanism for permitting exports under compulsory license. None of the parties involved in the negotiations believed that this was the result achieved, nor did the negotiators overlook the possibility of attaining a more user-friendly or expeditious process. The fact is that WTO Members negotiating on behalf of the originator pharmaceutical industry would not accept such a solution. It is doubtful that the basic positions of the Members

46 As of 13 September 2007, 10 WTO Members had formally accepted the Amendment: (i) United States (17 December 2005); (ii) Switzerland (13 September 2006); (iii) El Salvador (19 September 2006); (iv) Rep. of Korea (24 January 2007); (v) Norway (5 February 2007); (vi) India (26 March 2007); (vii) Philippines (30 March 2007); (viii) Israel (10 August 2007); (ix) Japan (31 August 2007) (x) Australia (12 September 2007). Information from WTO website at <http://www.wto.org. Ratification by the European Communities is pending approval of the European Parliament. The 'European Communities' is the formal Member of the WTO, along with each of the Member States of the EU. Presumably it is the 'European Communities' that would submit an instrument of acceptance to the WTO regarding the Amendment on behalf of the 'regional entity in Europe'.

47 See above n 37.

48 See above n 36.

49 See generally, Abbott, 'WTO Medicines Decision', above n 27 and Frederick M. Abbott and Rudolph van Puymbroeck, Compulsory Licensing for Public Health, A Guide and Model Documents for Implementation of the Doha Declaration Paragraph 6 Decision, World Bank Working Paper No. 61 (2005) [hereinafter 'World Bank Models'].

50 See above $\mathrm{n} 41$. It is interesting to note that while the EU was arguably the key architect of most of the limitations incorporated into the Amendment, the EU has adopted a Regulation to implement the Waiver Decision that shows a strong appreciation for the flexibilities that remain open to countries in making use of the system. See Abbott and Reichman, Study, above n 43 (analyzing the EU Implementing Regulation), above n 39. 
that played leading roles in the negotiations have significantly changed since the Waiver Decision was adopted. ${ }^{51}$

The Waiver Decision was the result of a long and complex negotiation among a substantial number of interested stakeholders, many of whom had widely different perspectives regarding the optimal outcome. Both the Waiver and the Amendment nonetheless represent a formal lowering of intellectual property (IP) protection standards imposed by the TRIPS Agreement. The traditional demandeurs of high standards of IP protection lose something they gained in the GATT Uruguay Round negotiations.

Empirically, moreover, because the transitional periods pertaining to patented pharmaceuticals under the TRIPS Agreement have only recently expired, the WTO lacks experience with the operation of the Waiver Decision or with the few implementing regulations that Members have adopted to date. ${ }^{52}$ Indeed, Rwanda in 2007, has become the first country to trigger the mechanisms established by the 2003 Waiver. ${ }^{53}$ Thus, there is neither a strong experiential basis for recommending acceptance of the Amendment, nor of declining to accept it. The question is largely political, in the sense that one must ask whether, and from whose perspective, an 'improved' Amendment might be negotiated or the chances for its effective implementation might be strengthened.

The authors are inclined to believe there is not much room in the present global political environment for negotiating a different deal from the one presently on the table. They also believe that the Amendment can play a net positive role from the standpoint of public health, even if it is not the optimal solution from the perspective of any interested stakeholder. While it is virtually impossible to predict whether the negotiating environment will change in the direction of improving the terms of the Amendment, there is some possibility that time will work against the existing waiver solution, notwithstanding the legal commitment by WTO Members that it should continue in effect indefinitely (until an Amendment is accepted by all Members). ${ }^{54}$ These considerations may ultimately argue in favor of ratifying and accepting the Amendment, imperfect though it may be.

51 The current G-8 focus on IP enforcement led by the German presidency, and the negotiating texts of EU Economic Partnership Agreements, suggest that the EU would not negotiate again today certain more permissive aspects of the Amendment, that it accepted in the past.

52 Including Canada, China, the EU, India, Norway and Switzerland (in process). See e.g. Abbott, 'WTO Medicines Decision', above n 27.

53 See Rwanda, Notification Under Paragraph 2(a) of the Decision of 30 August 2003 on the Implementation of Paragraph 6 of the Doha Declaration on the TRIPS Agreement and Public Health, Circulated 17 July 2007, WTO Council for TRIPS, IP/N/9/RWA/1, 19 July 2007.

54 See Waiver Decision, above n 36, at para 11. 


\section{A. India and the problem of exports under Article 31(f)}

To set the Amendment in context, we note that the potential problem posed by Article 31(f) of the TRIPS Agreement was identified prior to the decision by developing countries to initiate, in June 2001, a review within the TRIPS Council of the effects of the agreement on public health. While Article 31 generally permits WTO Members to issue compulsory licenses, subject to certain procedural requirements, on grounds of their own choosing, ${ }^{55}$ Article 31(f) limits exports under these licenses by requiring that 'any such use shall be authorized predominantly for the supply of the domestic market of the Member authorizing such use'. ${ }^{56}$

The core of the problem was recognition that, on 1 January 2005, India would be required to implement pharmaceutical product patent protection, and to review the pharmaceutical patent applications that were collected in its 'mailbox' between 1 January 1995 and 31 December 2004. Because India-unlike most developing countries-had taken advantage of the 10 -year transition period for providing pharmaceutical product patent protection, it had developed and maintained a world-class generic production capacity for drugs that were otherwise on-patent in developed (and many developing) countries. It was this unique generic production capacity that had enabled Indian manufacturers to break the price stranglehold of the originator companies with respect to key antiretroviral (ARV) treatments. ${ }^{57}$

Because the TRIPS Agreement forced India to patent pharmaceutical products developed after 1 January 2005, new drugs, such as second- or third-line ARVs, would probably not be available in generic form, and some first-line ARVs might become subject to essentially late-stage patent protection. ${ }^{58}$ The precise effects of the 1 January 2005 transition in India would largely depend on the terms and implementation of India's amended Patent Act.

55 See Reichman with Hasenzahl, above n 34.

56 TRIPS Agreement, above n 1, Article 31(f).

57 CIPLA offered annual per patient ARV treatment at about US $\$ 350$ when the originator prices were in the $\$ 10,000$ range. This revolutionized the HIV-AIDS treatment environment in the developing world. See Medecins Sans Frontieres (MSF), Untangling the web of price reductions, a pricing guide for the purchase of ARVs for developing countries, 8th edn, at 10, available at $<$ http://www.accessmedmsf.org/documents/untanglingtheweb\%208.pdf $>$. See also Abbott, 'WTO Medicines Decision', above n 27, at 320-24. It appeared that a substantial part of the first-line ARV drug library was invented and patented outside India prior to initiation of the mailbox requirement on 1 January 1995, and those drugs (at least in noncombination form) would not be subject to patenting. There was some question with regard to combinations, such as the widely used 'Combivir' patented outside India by Glaxo. The potential for patenting of combinations may depend on interpretation of the specific terms of India's new patent legislation. For a few ARVs, there might be issues regarding the appropriate filing and/or priority date that would influence whether or not the drugs would come under patent.

${ }^{58}$ See above $\mathrm{n} 57$. 
From the earliest days of developing-country consideration of the Article 31(f) problem, moreover, it was widely recognized that the need for low-cost generic supplies of newer medicines in developing countries extended well beyond ARVs, or treatment for malaria, tuberculosis and other infectious diseases. Coronary disease, cancer, diabetes, asthma and other disorders are major causes of morbidity and mortality in developing countries, as WHO statistical reports demonstrate. Therefore, any solution to the Article 31(f) problem had necessarily to extend beyond HIV-AIDS.

Given these premises, the developing countries attempted to establish a straightforward and expeditious solution that would rely on both Articles 30 and 31 of the TRIPS Agreement. First, they wanted an express understanding that WTO Members are able to use the Article 30 provision on exceptions to the scope of patent protection in order to authorize production and export 'to address public health needs in importing Members'. ${ }^{59}$ Under the logic of this approach, a Member authorizing exports to another country that lacked production capacity allowing it to proceed under a compulsory license of its own, would be viewed as having inflicted minimal harm on the patentee in the exporting country. Second, based on the underlying concept of 'comity' familiar to international lawyers, WTO Members with adequate capacity would have been authorized to 'give effect' to compulsory licenses issued by other members, and to export pursuant to those licenses, ${ }^{60}$ without any requirement for back-to-back licensing, as was ultimately adopted in the Waiver Decision and Protocol of Amendment. ${ }^{61}$

However, both the United States and the European Union (EU) rejected this proposal by the developing countries to resolve the Article 31(f) problem at the Doha Ministerial Conference in November 2001, and instead negotiated the well-known Paragraph 6 formula. ${ }^{62}$ Paragraph 6 triggered two

59 General Council, Council for Trade-Related Aspects of Intellectual Property Rights, Proposal by the African Group, et al., IP/C/W/312, WT/GC/W/450, 4 October 2001 (01-4803), available at http://www.wto.org.

${ }^{60}$ See suggestion in Communication from the European Communities and Their Member States, The relationship between the provisions of the TRIPS agreement and access to medicines, IP/C/W/280, 12 June 2001 and EU Commission, Compulsory Licensing and Data Protection, Legal Issues related to Compulsory Licensing under the TRIPS Agreement (referenced in para 13 of Communication to TRIPS Council), ibid. See further elaboration in Frederick M. Abbott, The TRIPS Agreement, Access to Medicines and the WTO Doha Ministerial Conference, Quaker United Nations Office (QUNO), Occasional Paper 7, 8 September 2001, at 13-15 [also published in 5 JWIP 15 (2002)], and Frederick M. Abbott, Compulsory Licensing for Public Health Needs: The TRIPS Agenda at the WTO after the Doha Declaration on Public Health, QUNO Occasional Paper No. 9, February 2002, at 29.

${ }^{61}$ See below text accompanying nn 87-105.

${ }^{62}$ Para 6 of the Doha Declaration, above n 33, provides:

'We recognize that WTO Members with insufficient or no manufacturing capacities in the pharmaceutical sector could face difficulties in making effective use of compulsory licensing under the TRIPS Agreement. We instruct the Council for TRIPS to find an expeditious solution to this problem and to report to the General Council before the end of 2002.' 
years of further negotiations leading to the adoption of the Waiver Decision in August 2003, followed by the adoption of the Protocol of Amendment in December 2005. In other words, the complications that emerged in the Waiver Decision and Amendment were the product of a decision to reject an administratively simple solution at Doha, and to construct a new, administratively complex regime, as envisioned in provisions introduced by the EU and the United States. ${ }^{63}$

\section{B. Terms of the WTO measures}

In the interests of conciseness, this article will not recount the step-by-step process that ultimately produced the specific terms of the Waiver Decision. ${ }^{64}$ The key elements and issues raised by those terms are briefly discussed subsequently.

\section{Scope of covered diseases}

From the outset of negotiations to address the Paragraph 6 mandate, developing countries demanded that the solution be applied broadly to diseases and treatments. ${ }^{65}$ The United States tried to restrict the scope of the solution to addressing HIV-AIDS, malaria, tuberculosis and a potentially small group of other infectious diseases, while seeking to limit the countries that would benefit from the solution. ${ }^{66}$ At a critical juncture in the negotiations, the EC proposed that the solution be confined to 'grave' public health problems, which raised the specter of WTO intervention to determine when a public health problem was serious enough to warrant attention. ${ }^{67}$ These strategies proved difficult to sustain, however. There is no public

${ }^{63}$ In fact, the bureaucratic complications which are ultimately reflected in the Amendment largely emanated from the European Commission. Consider, for example, the proposal from the EC to the TRIPS Council in June 2002, Communication from the European Communities and their Member States, Paragraph 6 of the Doha Declaration on the TRIPS Agreement and Public Health, IP/C/W/352, 20 June 2002.

${ }^{64}$ For a detailed analysis of the negotiating history of the August 30 Decision see Abbott, 'WTO Medicines Decision'. See also above n 27.

65 Substantive and Procedural Elements of a Report to the General Council under Paragraph 6 of the Declaration on the TRIPS Agreement and Public Health, Non-Paper Submitted to the Council for Trade-Related Aspects of Intellectual Property Rights by South Africa, 4 November 2002, WTO Ref: Job(02)/156. For list of supporting countries, see Abbott, 'WTO Medicines Decision', above n 27, at 328-29.

${ }^{66}$ It is worth noting that the United States initially proposed limiting permissible exporting countries to developing countries, but this was not strongly pursued. Moreover, the United States, like the European Union, was opposed to allowing use of the presumptively more liberal Article 30 approach, as distinct from the presumptively more restrictive Article 31 approach. For evidence that many or most of the key restrictions in the August 30 Decision and the Protocol of Amendment originated with, or were strongly supported by the EU, after considerable internal deliberation in the 133 Committee of the European Council, see e.g. MD: 494/02 REV 1, dated 29 October 2002, with interlineated suggestions from the Commission.

${ }^{67}$ Paragraph 6 of the Doha Declaration on the TRIPs Agreement and Public Health: Elements for a compromise solution, Reprinted in Inside US Trade as Text: EU TRIPS Paper, 1 November 2002. The same EC proposal sought to require that formulation of active 
health justification for denying patients access to treatments for certain diseases because trade officials have decided that some diseases should be on (or off) an official list.

Developing countries remained firm in rejecting the idea of restricting the solution to a limited scope of diseases, and their position ultimately prevailed. In defining 'pharmaceutical product', both the Waiver Decision and pending Amendment establish a broad subject matter scope of the medicines and related supplies that may be furnished pursuant to the system. ${ }^{68}$ The definition refers to products 'of the pharmaceutical sector needed to address the public health problems as recognized in paragraph 1 of the Declaration on the TRIPS Agreement and Public Health'.

Paragraph 1 of the Doha Declaration does not contain any limitation on the application of the Declaration to specific diseases or medicines. The definition of pharmaceutical product used in the Waiver Decision and Amendment expressly extends to active ingredients as well as to diagnostic kits used for determining whether pharmaceutical treatments are needed. The definition is also broad enough to include vaccines, because vaccines are 'products of the pharmaceutical sector'. ${ }^{6}$

\section{General notification and eligible importing countries}

There are at least two important forms of notification contemplated by the Waiver Decision and Amendment. The first is a general notification of intent to make use of the system as an importing country, which notification is required from all countries that use the system other than LDCs. ${ }^{70}$ The latter countries are thus already entitled to make use of the system without more on that account. The Waiver Decision and Amendment also provide that a WTO Member may notify the TRIPS Council that it does not intend to use the system as an importing country, or that it intends to use it only in a limited way. ${ }^{71}$ Practically all (if not all) OECD countries have made a

ingredients into final products was to take place in the importing Member if it maintained the capacity for formulation. This would in some cases require territorial division of the manufacturing process in a way that would make little sense from a cost-efficiency standpoint. The EC further sought to require that the patent holder should always have the right to make an offer of products at 'strongly reduced prices', which could be rejected on 'reasonable grounds'.

68 Para 1(a), Waiver Decision, above n 36; Para 2, Article 31bis, above n 37.

69 The Financial Times and the Wall Street fournal, recently opined, in response to the grant of a compulsory license on Plavix (clopidogrel) by Thailand, that WTO compulsory licensing rules were never intended to cover conditions such as heart disease. As noted below, members of the European Commission have expressed similar views. Although these opinions were offered in the context of Thailand's use of Article 31 of the TRIPS Agreement, and not the August 30 Decision, they provide continuing evidence that Pharma's advertising and lobbying influence will seek to distort the plain language of the TRIPS Agreement and Doha Declaration when it suits their purpose.

70 Para 1(b), Article 31bis, Annex, above n 37.

71 Ibid. 
notification of their intention not to use the system, or to use it in a limited way, including the European Communities and each of its Member States. A second form of notification, pertaining to use of the system in specific transactions, is discussed subsequently. ${ }^{72}$

As regards the general notice obligation imposed on would-be importing countries, transaction costs may be kept to a minimum by using World Bank standard forms prepared for this purpose. ${ }^{73}$ Because no special information is required, a generic formulation of intent should suffice. It remains, of course, a pointless exercise, which follows from the developed countries' strategy of loading-up the Waiver Decision and Amendment with bureaucratic requirements.

LDC Members are exempt from this general notification requirement, which means that more than 30 WTO Members already are eligible to use the system. As discussed subsequently, Rwanda has become the first WTO Member to make notification of its specific intention to use the system. Because Rwanda is an LDC, it was exempt from the requirement to make an initial general notification.

Some commentators have wondered why no developing country so far made the general notification of intent to use the system to the TRIPS Council. Whether other governments have neglected to make notification because of a lack of confidence in the system is difficult to assess. It would become clearer if a country that considered using the system had rejected such use because of potential obstacles, but the authors are not aware of any such case.

Observers have also suggested that the failure to use the system may reflect the developing countries' fears of hostile criticism (or perhaps even retaliatory penalties) from OECD countries, as exemplified by reactions to the recent grants of compulsory licenses by Thailand and Brazil. Industry groups in the OECD and some media outlets have implied that these countries are hostile to foreign direct investment because they threaten inviolable rights in patents. They are also castigated for failing to act as full-fledged participants in globalization, and have been threatened with adverse economic consequences. $^{74}$

Whether pressure of this kind would pragmatically translate into a palpable reduction in foreign direct investment seems a doubtful proposition at best. Would, for example, a manufacturer of computer equipment decide not to invest in an otherwise attractive business environment because the host country had taken steps to protect the public health of its citizens, even if this included the grant of a compulsory license? That same company might just as well view measures taken for the protection of public health as

\footnotetext{
72 See below text accompanying nn 97-8.

73 See World Bank Models, above n 49.

74 See below, text accompanying nn 146-58.
} 
a positive inducement, in part because company health expenditures might be lowered.

Nevertheless, in requiring eligible importing countries to deposit a general notification of intent to use, opponents of the system may in fact have imposed a political barrier that limits its usefulness. In this connection, we note that in 2001 US authorities threatened to issue compulsory licenses with regard to stockpiling Cipro for an anthrax scare. Health and Human Services Secretary Michael Leavitt did much the same thing regarding access to Tamiflu. ${ }^{75}$ We also note that France and Belgium have recently enacted statutes permitting accelerated compulsory licensing of pharmaceuticals when needed. While their official positions hostile to compulsory licensing thus seem intended to inhibit action by foreign governments, they are not actually considered to constrain either the EU or the United States. ${ }^{76}$

\section{Determination as to insufficient or no capacity}

In order to be eligible to import medicines in a given case, under Article 31 bis, a country must either (1) be an LDC, or (2) make a determination that it has insufficient or no manufacturing capacity for the product in question. ${ }^{77}$ The determination regarding capacity, which is made by the importing country, excludes production facilities that the patent holder owns or controls. It applies to the specific product in question, and not generally to the country's pharmaceutical industry. ${ }^{78}$ Once the importing Member has developed its own adequate capacity, it is expected to cease use of the system.

This requirement imposes no significant burden on a prospective importing Member. When there is adequate domestic capacity to produce the product in a way that would reasonably satisfy the country's needs, there is no reason to obtain supplies elsewhere. Developing WTO Members succeeded on this issue, despite a proposal to divide the API and formulation markets (which might have created significant inefficiencies). ${ }^{79}$

75 US Representative Joe Barton (R-Tx) Holds a Hearing on Pandemic Flu Preparedness, House Energy And Commerce Committee, FDCH Political Transcripts, 8 November 2005, (exchange between HHS Sec'y Michael Leavitt and Representative Tom Allen), Lexis-Nexis News database. Roche agreed to increase its manufacturing of Tamiflu within the United States at the insistence of Health and Human Services following studies indicating that foreign sources of supply would be unreliable in a crisis. See also Roche Press Release, infra n. 125 .

76 In fact, the United States makes greater routine use of compulsory licensing of patent inventions for a variety of government purposes than most other countries combined. See generally, Jerome H. Reichman with Catherine Hasenzahl, Non-Voluntary Licensing of Patented Inventions: The Law and Practice of the United States, (Part III) (ICTSD/UNCTAD 2003) (citing authorities).

77 Para 2(a)(ii), Article 31bis, Annex, and Appendix to Annex, above n 37.

78 Ibid.

79 See above n 67. The 'Chairperson's Statement', discussed below, text accompanying nn 113 15, indicates that 'To promote transparency and avoid controversy, notifications under paragraph 2(a)(ii) of the Decision would include information on how the Member in question 


\section{Licensing and conditions}

The procedural and substantive requirements that govern the issuance of compulsory licenses by importing (where applicable) and exporting countries, as well as the conditions and notifications connected with that licensing, constitute the principal potential obstacles to effective use of the Amendment.

(a) Importing Members An importing member need not issue a domestic compulsory license when there is no applicable patent. Because LDCs are authorized to ignore or suspend patent protection, ${ }^{80}$ they too need not issue domestic compulsory licenses if they choose to produce or import medicines otherwise covered by patents. An importing member that is not exempt (per the above) must issue a compulsory license prior to importation, and it must notify the TRIPS Council of its intent to issue (or its issuance of) the license. ${ }^{81}$

Although compulsory licensing may entail a number of administrative complications, there are legitimate ways to avoid a substantial part of them. For example, a license issued for public noncommercial use or for national emergency or circumstance of extreme urgency does not require prior negotiation with, or even notification of, the patent holder (pursuant to Article 31(b), TRIPS Agreement, which applies to the Amendment procedure). ${ }^{82}$ Only in the case where a party is seeking a compulsory license for ordinary commercial use do the requirements of prior negotiation with the patent holder and prior notification apply. It therefore becomes legally possible to ensure that action on the importing side (as well as on the exporting side) occurs in an expeditious manner.

It is worth noting that action to remedy anticompetitive practices also obviates both the need for prior negotiation with the patentee and the limits on exports under Article 31(f), ${ }^{83}$ which would otherwise require recourse to the Amendment. However, actions to correct anticompetitive practices require some judicial or administrative process, ${ }^{84}$ which takes time. Once the process is completed, the prosecuting government is also freed from the duty to provide adequate remuneration and may, instead, penalize the patentee

had established, in accordance with the Annex, that it has insufficient or no manufacturing capacities in the pharmaceutical sector.' Irrespective of the legal status of the Chairperson's Statement, this adds nothing material to the Amendment. A statement that the importing country had examined relevant available data would suffice.

${ }^{80}$ See Para 2(a) (iii) and n 6, Waiver Decision, above n 36, and World Bank Models, above n 49, at $19-21$.

81 See Para 2(a)(iii), Waiver Decision, above $\mathrm{n} 36$.

82 See e.g. para 2(a)(iii), ibid, for continued applicability of Article 31, except as otherwise amended. In addition, the possibility for injunctive relief need not be available with respect to government use.

83 TRIPS Agreement, above n 1, Article $31(\mathrm{k})$.

84 Ibid. 
for its conduct. ${ }^{85}$ In this connection, the Italian Competition Commission has recently issued three compulsory licenses against major pharmaceutical companies for refusals to deal, and it has imposed royalty-free licenses to boot. ${ }^{86}$

Under amended Article 31bis, the importing Member must specify the name of the product(s) and the expected quantities to be imported, and make notification of that to the TRIPS Council. ${ }^{87}$ While some commentary has suggested that this requirement inhibits effective use of the system, ${ }^{88}$ it is not necessarily true. The Amendment does not demand a particular fixed formula, and there are a several ways to express a relatively subjective indication (e.g. the quantity needed to treat an approximate sized group of patients over an approximate period of time). Nothing in the Amendment prevents a Member from modifying the quantity over time as needs change or become clearer. ${ }^{89}$ While it would have been simpler to avoid a statement of expected quantity, this requirement, standing alone, does not necessarily constitute a significant obstacle.

Also criticized is the provision requiring prospective suppliers in exporting Members to produce on a case-by-case, license-by-license basis. ${ }^{90}$ Prospective exporters accordingly find it harder to make decisions and investments necessary to scale-up production due to the uncertain size of import markets. This issue will be further addressed in the context of the requirements imposed on exporting Members. Nevertheless, so long as 'predominant' exports are considered a form of 'exception' under Article 31(f) that requires specific procedural attention, investment planning may remain problematic unless action to pool compulsory licenses in appropriate procurement cases - as explained subsequently — suffices to address the problem. ${ }^{91}$

In July 2007, Rwanda, an LDC, became the first country to submit notice of intent to use the system in order to import specific ARV drugs from Canada. ${ }^{92}$ Rwanda relied on World Bank model forms in making this notification. Rwanda's has thus invoked Canada's administratively complex

${ }^{85}$ Ibid. See generally, Thomas Cottier, 'The Doha Waiver and Its Effects on the Nature of the TRIPS System and on Competition Law-The Impact of Human Rights', in Intellectual Property, Public Policy, and International Trade, I. Govaere and H. Ullrich (eds), College of Europe Studies, No. 61, 2006, 173, 196-8 (viewing Waiver Decision as substitute for undeveloped competition law and policies in poor countries).

${ }^{86}$ See e.g. Press Release, Pharmaceuticals: Antitrust Authority Rules Merck Must Grant Free Licences For The Active Ingredient Finasteride, A364 - Merck - Active Ingredients (Conclusion of Investigation), http://www.agcm.it/agcm_eng/COSTAMPA/E_PRESS.NSF/ 92e82eb9012a8bc6c125652a00287fbd/28653 b373e56772ac12572ab003a4d68

87 Para 2(a)(i), Article 31 bis, Annex, above n 37.

${ }^{88}$ See e.g. MSF Access to Medicines Campaign, Neither Expeditious, Nor a Solution, above n 41, at 4 .

${ }^{89}$ See e.g. World Bank Models, above n 49, at 23-24.

${ }^{90}$ See e.g. MSF Access to Medicines Campaign, Neither Expeditious, Nor a Solution, above n 41, at 4 .

91 See below section 'Making the Amendment System Work'.

92 See Rwanda notification, above n 53; see also World Bank Models, above n 49, at 19-20. 
implementing legislation, which entails requirements in addition to those imposed by the Waiver Decision. ${ }^{93}$

(b) Exporting Members Under the proposed Amendment (as under the Waiver), an exporting Member is also required to issue a compulsory license subject to conditions. ${ }^{94}$ The authorized manufacturer should only export the quantities needed (and notified) by the importing Member(s). ${ }^{95}$ Product should be clearly identified as having been produced under this system, which may entail special packaging and/or labeling, and/or special shaping or coloring, if the distinctions are feasible and do not significantly affect price. ${ }^{96}$ The exporting licensee is required to post destination and identification information regarding shipments on a web site, ${ }^{97}$ and it must also notify the TRIPS Council of the issuance of the license and its conditions, including the expected quantities of production and destination(s). ${ }^{98}$

As with respect to the importing Member, a compulsory license issued by the exporting Member for public noncommercial use or for national emergency or circumstance of extreme urgency does not require prior negotiation with, or notification of, the patent holder. ${ }^{99}$ Thus, under the circumstances envisioned by Article 31(b) of the TRIPS Agreement, a compulsory licensing transaction may be pursued expeditiously through back-to-back licenses that take advantage of 'fast-track' possibilities. ${ }^{100}$

However, one developed country government has expressed the view that an emergency in the importing country would not justify 'fast track' procedures in the exporting country. ${ }^{101}$ While this paradoxical position has been

93 Canadian Access to Medicines Regime, Ch 23, Statutes of Canada (2004).

94 Para 2(b), Article 31bis, Annex, above n 37.

95 Para 2(b)(i), Ibid.

96 Para 2(b)(ii), Ibid. This provision is also addressed in the Chairperson Statement, below nn 113-115. Irrespective of the legal status of the Chairperson Statement, it is unlikely to affect this aspect of the Amendment.

97 Para 2(b)(iii), Article 31bis, Annex, above n 37.

98 Para 2(c), Ibid.

99 See e.g. para 2(a)(iii), Ibid (specifying continued applicability of Article 31, except as otherwise amended).

100 The 'fast-track' terminology in this regard was initially adopted by a European Commission negotiating team and used in an article on the Waiver Decision published subsequent to its adoption. See Paul Vandoren and Jean Charles Van Eeckhaute, 'The WTO Decision on Paragraph 6 of the Doha Declaration on the TRIPS Agreement and Public Health: Making It Work', 6J World Intell Prop L 779, 783 (2003) (stating that under Article 31 'procedures to grant compulsory licenses are not necessarily cumbersome and lengthy' but, rather, 'minimal and flexible').

101 See Abbott, 'WTO Medicines Decision', above n 27, at 342, for earlier reference to this Canadian position. The position was reiterated, and attributed to the Ministry of Justice, at a public meeting on review of Canada's legislation held in Ottawa on 19-21 April 2007 (author's notes). It is self-evident that the entire object and purpose of negotiation of the Waiver and Amendment was to allow an exporting Member to make use of the 'fast-track' procedure to address a situation of emergency, extreme urgency or public noncommercial use in the eligible importing Member. The whole process is designed to meet the public health needs of the importing country that lacks manufacturing capacity. 
rejected by other governments in their implementing legislation, it may undermine the extent to which developing country governments believe they can rely on the good faith of negotiators at the WTO.

As a general matter, compiling the information required by the TRIPS Council concerning the grant of a compulsory license should not unduly burden the exporting Member. Reputable pharmaceutical producers generate detailed production and shipping records in the ordinary course of business, and posting such information on the Internet should be a minor matter. Although there might be some cases where specially identifying a product could impose difficulties, in the ordinary case finished product packaging is relatively easy to modify, and identification through such modifications or labeling should be acceptable under the terms of the Amendment. ${ }^{102}$

A potentially more serious obstacle for the prospective exporter is the requirement to produce only amounts needed to satisfy the requirements of licensees or other importers (e.g. LDCs operating under an exemption) as notified to the TRIPS Council. Prospective producers in exporting countries may thus refrain from constructing new facilities 'on speculation' that a sufficient number of orders will be received in the end. However, this outcome is consistent with respect for the rights of patent holders under the terms of the TRIPS Agreement.

Other factors may ameliorate this potential problem. As with any production venture, the plant owner may visit prospective purchasers prior to undertaking capital expenditure, to obtain indications of intention to purchase and/or commitments. The recipient of a compulsory license under this system is not precluded from also obtaining a license for supply of its domestic market. Existing pharmaceutical production facilities may in some cases be modified to produce different drugs, without need to build a new facility, in which case, the transition costs may be modest. For example, a producer in India, Brazil or elsewhere might initiate relatively small-scale production under either a commercial license or a compulsory license for supply of the domestic market, and later solicit orders that would require it to make use of the Amendment. The costs of ramping up production in such cases may be lower than start-up costs from scratch.

Above all, pooled procurement strategies may be used by countries or groups of countries with long-term needs that can be identified in advance, which may facilitate long-term planning for potential exporters. For example, a group of countries in the Caribbean may decide that they have a long-term need for second- or third-line ARV treatments and they could jointly contract for purchase from an Indian or Brazilian supplier.

102 The language of the Amendment suggests that a producer should not be required to purchase new formulation or stamping equipment solely for this purpose, but might make some adjustments to existing production processes. 
This approach will be more fully developed in connection with our discussion of Regional Supply Centers subsequently. ${ }^{103}$

\section{Remuneration}

One potential consequence of the issuance of double compulsory licenses in the importing and exporting Members was that the remuneration provided for under Article 31(h) of the TRIPS Agreement might have to be paid twice. The Amendment avoids this outcome by providing that adequate remuneration need only be paid in the country of export, taking into account the economic circumstances of the importing country. ${ }^{104}$ This reasonable solution to the remuneration issue should not likely lead to difficulties.

\section{Measures to prevent diversion and non-authorized importation}

The Amendment obligates importing Members to take reasonable and proportionate measures to prevent diversion or re-exportation of pharmaceutical products received under the system. ${ }^{105}$ There is provision for potential assistance from developed to developing Members in implementing an anti-diversion system, if requested. This provision, which is directed to governments, need not materially inhibit use of the system or impose unreasonable costs. Drug importation should ordinarily be subject to close supply chain management, and steps taken to ensure the integrity of supply are likely to prove useful from a public health perspective as well.

The Amendment also requires Members to enable patent holders to protect against unauthorized importation of products manufactured under the system and diverted into their markets. ${ }^{106}$ However, Members are not required to establish mechanisms for this purpose beyond those already available under the TRIPS Agreement. ${ }^{107}$ Implicit in this scheme is an understanding that medicines produced under the relevant compulsory licenses should not be treated as 'lawful parallel imports' after having initially been placed on the market. This result follows logically from the design of the system, which limits exports to the intended destination (although another approach to re-exports might reasonably have been pursued).

\section{Special regional treatment}

The Amendment makes special provision for Members that belong to regional trade agreements of which at least half the members 'currently' are LDCs. ${ }^{108}$ This provision permits pharmaceutical products imported into one Member of the eligible group under a compulsory license to be

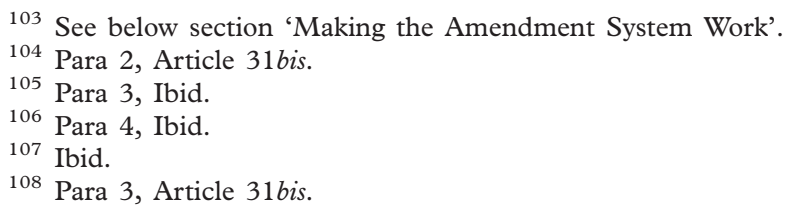


re-exported to other Members of the group without additional export licensing. However, it does not exempt the importing countries from issuing separate compulsory licenses where otherwise applicable ${ }^{109}$ (i.e. when there is a patent or, in the case of an LDC, when it has not elected to disapply the patent). There is also some provision for developed country assistance in establishing systems for the grant of regional patents to facilitate use of this concession.

Nonetheless, this provision for special treatment of a regional alliance remains severely restricted. The EU, which was instrumental in imposing these limitations during the negotiations, insisted that the solution should be limited to what is effectively sub-Saharan Africa. It rejected proposals that would have made it unnecessary for importing countries to issue compulsory licenses when re-exportation had otherwise been enabled. ${ }^{110}$

\section{Non-violation causes of action}

The Amendment expressly precludes nonviolation nullification or impairment causes of action, and situation causes of action, from being initiated in dispute settlement proceedings related to the Amendment. ${ }^{111}$ This prohibition is important because the general situation regarding nonviolation complaints under the TRIPS Agreement remains uncertain, and the possibility of such complaints might have created substantial insecurity for countries inclined to use the system. ${ }^{112}$

\section{The Chairperson's Statement}

When, after protracted negotiations, efforts to limit the 'scope of diseases' covered by the Waiver Decision failed, ${ }^{113}$ a face-saving formula was devised to enable the United States to sign off on it. This formula ultimately resulted in a statement read out by the Chair of the General Council prior to adoption of the Waiver Decision on 30 August 2003, and again prior to adoption of the Protocol on 6 December 2005 (the Chairperson's Statement).

As a practical matter, the only controversial provision of the Chairperson's Statement is the shared understanding that:

First, Members recognize that the system that will be established by the Decision should be used in good faith to protect public health and, without prejudice to paragraph 3 of Article 31 bis of the amendment

${ }^{109}$ For suggestions about pooling such licenses, see below text accompanying nn 232-41.

110 The provision for assistance in regional patenting was viewed by developing country negotiators as part of an EU strategy for making it easier for EU pharmaceutical companies to control the market.

${ }_{111}$ Para 4, Article 31bis.

112 See e.g. UNCTAD-ICTSD Resource Book, above n 1, at $668 \mathrm{ff}$.

${ }^{113}$ See above text accompanying nn 65-9. For details, including US statement to TRIPS Council, see Abbott, 'WTO Medicines Decision', above n 27, at 331. 
[or paragraph 6 of the Waiver Decision], not be an instrument to pursue industrial or commercial policy objectives. ${ }^{114}$

The United States had initially proposed that use of the Waiver Decision should 'not [be] for commercial gain,' but developing country negotiators promptly rejected this proposal. The final formula indicates that the intention of the system is to support public health needs, and not primarily to advance industrial policy objectives. We do not expect this statement to inhibit use of the system, whatever its legal status may turn out to be. ${ }^{115} \mathrm{It}$ seems unlikely that any WTO Member issuing a compulsory license for export of a pharmaceutical product to assist needy countries that lacked manufacturing capacity of their own would be failing to advance public health objectives, even though the exporting country may benefit from the venture.

\section{Technology transfer}

The Amendment recognizes the desirability of improving pharmaceutical production capacity in countries with insufficient or no capacity, and it encourages Members to 'use the system in the way which would promote this objective'. ${ }^{116}$ It also includes an 'undertaking' by Members to address this problem within the framework of Article 66.2 of the TRIPS Agreement, and related commitments to LDCs. ${ }^{117}$

The German government, in association with United Nations Conference on Trade and Development (UNCTAD), United Nations Industrial Development Organization (UNIDO) and the UK Department for International Development (DFID), is undertaking a program to improve production capacity in certain LDCs of Africa and elsewhere, which represents an example of positive implementation of this undertaking. The United States has also provided funding for the study of transfer of technology options for the pharmaceutical sector in Latin America, one of which studies was undertaken by an author of this article. ${ }^{118}$

These initiatives suggest that there are concrete mechanisms by which technologically advanced countries might support the improvement of pharmaceutical research, development and production capacity in developing

114 Text of Chairperson's Statement is available at http://www/wto.org.

${ }^{115}$ Nonetheless, there is considerable controversy concerning the legal status of the Chairperson's Statement.

${ }_{116}$ Para 6, Article 31bis, Annex, above n 37.

117 TRIPS Agreement, above n 1, Article 61.2, requires developed country members to 'provide incentives to enterprises and institutions in their territories for the purpose of promoting and encouraging technology transfer', to LDCs, so that the latter 'may create a sound and viable technological base'.

${ }^{118}$ Frederick Abbott has served as technical expert for a project funded by USAID regarding transfer of technology in the pharmaceutical sector with respect to Colombia, which project has also involved extensive consultations in Brazil. Such projects are over and above the requirements of Article 66.2, which addresses LDCs. 
countries. Yet, very limited financial resources have so far been committed to such endeavors, and it is not clear that developed country governments are genuinely prepared to promote capacity-building objectives of this kind.

\section{Implementing regulations}

Given the deliberate limitations built into the pending Amendment, the ratification process immediately poses the question whether, from a public health standpoint, it can and will be implemented in a manner that enables countries without adequate production capacity to make effective use of compulsory licensing. How potential exporting countries resolve internal tensions between their research-based pharmaceutical industries and their generic producers will affect the end result.

For example, the initial proposal for an implementing Regulation from the European Commission contained a number of restrictions and limitations that would have substantially inhibited effective use of the Waiver Decision and Amendment. Among the most important deficiencies, that proposal did not acknowledge the possibility of using the fast-track procedure. ${ }^{119}$ Notwithstanding this problematic initial response, and through successful intervention by the European Parliament, ${ }^{120}$ the EU ultimately adopted an implementing Regulation that appears to successfully incorporate most of the flexibilities available to WTO Members in making use of the Waiver Decision. $^{121}$

\section{Tentative evaluation of the pending enactments}

One of the common criticisms directed at the Waiver Decision (and Amendment) is that, until July 2007, its legal machinery had not been used despite its provisional adoption in August 2003. It seems logical to follow that

119 See e.g. European Parliament, Committee on International Trade, Report on the Proposal for a Regulation of the European Parliament and of the Council on compulsory licensing of patents relating to the manufacture of pharmaceutical products for export to countries with public health problems [(Com (2004)] 0737-C60168/2004-2004/0258 (COD), A6-0242/ 2005, at 7 [hereinafter EP Committee on International Trade, Report (2005)] (recommending that the Community should 'encourage...the transfer of technology, research, capacity strengthening regional supply systems and help with registration in order to facilitate and increase the production of pharmaceutical products by the developing countries themselves'.).

120 Proposal for a Regulation of the European Parliament and of the Council on compulsory licensing of patents relating to the manufacture of pharmaceutical products for export to countries with public health problems, Brussels, COM(2004) 737 final, 29 October 2004. See also Carlos M. Correa, Policy Paper, Assessment of the Proposed EU Regulation on the Compulsory Licensing of Generic Drugs for Export to Developing Countries, Policy Department, European Parliament, EP/ExPol/2004/07 01/02/2005.

${ }^{121}$ Regulation (EC) No 816/2006 of the European Parliament and of the Council of 17 May 2006 on compulsory licensing of patents relating to the manufacture of pharmaceutical products for export to countries with public health problems, OJ L 157/1, 9 June 2006, available at $<$ http://www.europarl.europa.eu/oeil/FindByProcnum.do?lang=2\&procnum $=\mathrm{COD} / 2004 / 0258>$. For a detailed explanation of the flexibilities in the EU Regulation, see Abbott and Reichman Study, above n 43 at 19-21. 
because the Waiver Decision has seldom been used, it must be ineffective. We believe this particular line of criticism to be both premature and unconvincing. Nor should one conclude that these instruments have failed to play a significant role in influencing access to essential medicines.

In 2005, as worldwide concerns about the spread of a deadly form of avian flu increased, Taiwan announced that it would issue a compulsory license for the local production of Roche's patented Tamiflu (oseltamivir) antiviral. ${ }^{122}$ Following expressions of concern by other countries regarding potential limits on the availability of Tamiflu from Roche, the Swiss pharmaceutical company issued voluntary licenses to a number of producers that permitted stockpiles to be increased, ${ }^{123}$ including producers in China (two suppliers), India and South Africa. ${ }^{124}$ Although Roche was said to have entered into voluntary licensing agreements with US generic manufacturers to increase production under pressure from members of Congress, ${ }^{125}$ Roche itself reports that it stepped up its own controlled production in the United States at the request of the Department of Health and Human Services. ${ }^{126}$

Roche's actions with respect to the supply of Tamiflu were taken in the shadow of the Waiver Decision and Amendment, which would have permitted the export of its product under compulsory license to countries without adequate manufacturing capacity. A producer acting under compulsory license in Taiwan, China or India could fill orders from developing countries around the world (most developed countries have opted out of the Amendment-based system). Compulsory licensing has traditionally served as an effective threat against which price reductions or voluntary

122 Kathrin Hille, Taiwan employs compulsory licensing for Tamiflu, FT.com, 25 November 2005. The report notes that Taiwan issued a domestic license with a number of limitations. However, its decision appeared to trigger announcements by other countries of plans to issue compulsory licenses, suggesting an incipient global movement to override the Roche patent, which might well have included export-import arrangements.

${ }^{123}$ Roche Media News, Roche update on Tamiflu global supply to meet future world demands-from partnerships to regional sub-licenses, Basel, 12 December 2005 (reporting voluntary license to Shanghai Pharmaceutical Group, and identification of twelve potential sub-licensees); Roche, Factsheet Tamiful, 17 November 2006, at http://www.roche.com/ med_mbtamiflu05e.pdf.

124 The Chinese license was reportedly issued under threat of compulsory license. See James Packard Love, Recent Examples of the Use of Compulsory Licensing on Patents, KEI Research Note 2007 (2), revised as of 6 May 2007, available at http://www.keionline.org/ misc-docs/recent_cls.pdf.

125 See e.g. California State Senate Health Committee Staff Analysis of Senate Bill 1763, April 2006, noting that, on 26 October 2005, 10 members of Congress sent a letter to Health and Human Services Secretary Michael Leavitt stating that compromising public health needs to protect patent rights is 'inexcusable' 'and requesting the immediate issuance of compulsory licenses for Tamiflu and Relenza so that generic manufacturers could begin producing necessary drugs to meet stockpile goals. In December of 2005, Roche reached a voluntary agreement with two US generic drug companies to increase production of Tamiflu.' See $<$ http://info.sen.ca.gov/pub/05-06/bill/sen/sb_17511800/sb_1763_cfa_20060424_152009_ sen_comm.html $>$.

${ }^{126}$ Roche recorded conference call MP3 file, 26 April 2007, from http://www.roche.com/home/ media/med_events/med_events_mb0407.htm. 
licenses may be negotiated, ${ }^{127}$ and it seems likely that the Waiver Decision played that role in the case of Tamiflu.

Even if one discounts the role of the Waiver Decision in this instance, it remains unsurprising that its framework has only just begun to be used. The factual premise underlying negotiation of the Waiver Decision and Amendment was the transition to take place in India on 1 January 2005. After that date, pharmaceutical mailbox patent applications would be processed, ${ }^{128}$ and new pharmaceutical products would become subject to patenting. While a resulting curtailment of generic supplies to world markets from India was anticipated, it could not be, and was not, immediate.

Even though Indian patent offices must process the mailbox applications, progress has been slow. Moreover, India's Patent Act amendments permit generic producers to continue supplying medicines already in production on 1 January 2005, upon payment of a reasonable royalty, and Glaxo decided against pursuing its Indian patent application for Combivir. ${ }^{129}$ As a result, Indian generic production and supply to world markets has yet to be curtailed.

While use of the system established by the Amendment could have been undertaken in other prospective exporting countries, or for other reasons, its slow start does not support the conclusion that it is unimportant. As countries face the growing need to supply second- and third-line ARV treatments, which are and will be patented in the principal countries of potential supply, such as China and India, demand for generic products should become intense. In that context, governments may well be prepared to overcome political inhibitions and seek to make use of the system. The recent issuance by Brazil and Thailand of compulsory licenses on Merck's patented Efavirenz drug evidences the growing pressures on public health budgets.

\section{The grants of compulsory licenses in Brazil and Thailand}

Recent grants of compulsory licenses in two middle-income developing countries have riveted attention on this legal device and heated up the political atmosphere, which indirectly affects the prospects for implementation of the pending Amendment. A brief survey of these developments is set out subsequently.

Let us clarify that the Waiver Decision did not apply to the government use licenses issued by Brazil and Thailand, nor would the Amendment have

127 See Reichman with Hasenzahl, Non-Voluntary Licenses of Patented Inventions, above n 34 See also Cottier, The Doha Waiver, above $\mathrm{n} 85$ (finding that 'the Waiver and Amendment have made an impact as one among many other factors'.).

128 See Abbott, WTO Medicines Decision, above n 27, at 320-3.

129 The Patents Act of 1970 (India), as amended 2005, section 11A(7). See GlaxoSmithKline Press Release, 10 August 2006, GSK patents and patent applications for Combivir, http:// www.gsk. com/ControllerServlet?appId $=4$ \&pageId $=402 \&$ newsid $=874$. 
applied (if and when it enters into force), at least as matters now stand with respect to foreign requests for supply. Neither Brazil nor Thailand issued its license for the purpose of exporting a predominant part of production to a country or countries without adequate pharmaceutical manufacturing capacity, which is the situation covered by the WTO's legislation under review.

These licenses were instead issued within the legal framework established by Article 31 of the TRIPS Agreement, and reaffirmed by the Doha Declaration, in a manner legally consistent with that framework. Nonetheless, the public health circumstances surrounding the issuance of these licenses, as well as the ensuing political reactions, are relevant to an assessment of the potential benefits of the Amendment.

\section{The case of Brazil}

Few countries in the world - and certainly among developing countrieshave devoted more attention to the problem of ensuring access to medicines than Brazil, and there is a comprehensive academic literature describing in detail the steps the Brazilian government and research institutions have taken to this end. ${ }^{130}$ To be clear, prior governments had been criticized for legislation favoring multinationals over the domestic industry, which created serious problems. A number of steps now being taken in Brazil are designed to rebalance the situation, so as to enhance local participation in more innovative parts of the pharmaceutical sector.

Prior to entry into force of the TRIPS Agreement on 1 January 1995 (which Brazil had strongly opposed), its domestic industry had produced a significant part of the APIs used in products sold on the domestic market. Because Brazil did not provide pharmaceutical product patent protection at that time, it could have taken advantage of the same ten-year transition period that India had invoked. ${ }^{131}$ However, in a decision strongly criticized by Brazilian public health experts, the government chose not only to provide pharmaceutical product patent protection from 1996 on, but also to voluntarily afford 'pipeline' measures that permitted the extension of patent protection beyond what would ordinarily have been available to holders of foreign patents. ${ }^{132}$

${ }^{130}$ See e.g. Intellectual Property in the Context of the WTO TRIPS Agreement: Challenges for Public Health, J. Bermudez and M.A. Oliveria (eds) (2004), Chs 7-9; Claudia Ines Chamas, Developing Innovative Capacity in Brazil to Meet Health Needs, MIHR Report to CIPIH, April 2005, WHO Ref. CIPIH Study 10d (DGR); O. Fabienne, D. Cristina, L. Hasenclever and C. Benjamin, TRIPS-Post 2005 in Southern Countries: The Sustainability of Public Health Policies at Stake, DIME Conference, London, September 2006, and Luciana Xavier de Lemos Capanema, A Indústria Farmacêutica Brasiliera e a Atuação do BNDES, 23 BNDES Setorial 193 (2006). Data regarding Brazil's pre-TRIPS APIs production is in Chamas, ibid., at $81-82$.

131 TRIPS Agreement, above n 1, Article 65.4.

132 Provided that their products had not been previously introduced on the Brazilian market. 
As a consequence of these decisions, between 1996 and 2005, Brazil lost almost all of its API production capacity, although not the basic technology that might be needed to reestablish it. Today, virtually all APIs used in the Brazilian pharmaceutical sector are imported, and there has been a staggering, disproportionate increase, in Brazilian expenditures on imports of pharmaceutical products.

At the same time, Brazil led the world in establishing universal public access to ARV treatment for HIV-AIDS. As part of a comprehensive strategy, Brazil relied on a system of public manufacturing facilities to produce reasonably affordable ARV treatments that were not covered by patents. However, several important ARVs, particularly those used as second-line treatment (i.e. when resistance to first-line treatment develops) were subsequently patented in Brazil by foreign multinational producers, and these drugs could not be produced locally without infringing those patents.

The cost to the Brazilian public health sector of purchasing the patented ARVs far exceeds the cost of purchasing locally produced (or imported) generic ARVs, and it imposes a significant burden on the public health budget. Because resistance to first-line ARVs among the group of patients treated in Brazil will increase over time, and because side-effect profiles of newer generation ARVs may be better than first-line alternatives, reliance on newer treatments seems likely to increase, with corresponding pressure on the public health expenditures.

For these reasons, the Brazilian government has used the threat of compulsory licensing to pressure foreign multinational patent holders to significantly lower the prices charged for ARVs. Up until April 2007, Brazil had not formally issued a compulsory license because the government reached negotiated settlements with foreign suppliers in every case. ${ }^{133}$

However, in April 2007, the Brazilian government ${ }^{134}$ decided to grant a compulsory license for public use of Merck's ${ }^{135}$ Brazilian patent on the ARV Efavirenz. ${ }^{136}$ This ARV is used in the treatment of approximately 75,000 of

133 The decision to pursue voluntary settlements had been criticized by important actors in the Brazilian public health sector because (i) in some cases, the results were perceived as too favorable to the foreign supplier and too restrictive on Brazilian public health authorities, and (ii) because the failure to initiate production in Brazil limits the learning experience and capacity of public and private pharmaceutical producers. In the end, reliance on foreign patent-holding suppliers continues at the present time.

134 See Q\&A from the Brazilian Ministry of Health on the Efavirenz CL-official translation from the Ministry of Health available on www.aids.gov.br, posted on IP-Health List Serve, 26 April 2007.

135 In Brazil, through its affiliate 'Merck Sharp and Dohme'. Ibid.

136 'Efavirenz is in the class of drugs called non-nucleoside reverse transcriptase inhibitors (NNRTIs), which helps keep the AIDS virus from reproducing in cells. This antiretroviral drug is used in combination with other antiretroviral agents for the treatment of HIV-1 infection.' US Food and Drug Administration, FDA Tentatively Approves Generic Efavirenz-Product Eligible To Be Considered Under the President's Emergency Plan for AIDS Relief, FDA News, 24 June 2005. 
the 200,000 patients under treatment in Brazil. ${ }^{137}$ Although Merck had offered to lower the annual per patient price of its drug from $\$ 580$ to $\$ 400$, there were generic versions available from India at $\$ 165$ per patient per year. Brazil estimates a cost-saving of $\$ 30$ million per year to its public health procurement budget from shifting to generic imports. ${ }^{138}$

Brazil's national pharmaceutical laboratory and producers also plan to transition to local production. ${ }^{139}$ In this connection, we note that the US President's Emergency Plan for AIDS Relief (PEPFAR) authorizes the purchase of generic Efavirenz from at least one Indian supplier (Aurobindo). The latest report from PEPFAR explains the substantial cost-saving the US government is achieving in its treatment program through a shift from originator to generic ARVs (including Efavirenz). ${ }^{140}$

\section{The case of Thailand}

Thailand covers a large part of its population with universal access to medicines through publicly funded government organizations, which provide universal access to HIV-AIDS treatment. ${ }^{141}$ Since the entry into force of the TRIPS Agreement, Thailand's budgetary expenditures for the provision of medicines have increased dramatically and now constitute approximately $10 \%$ of the total government budget.

From November through February 2007, the government of Thailand issued compulsory ('government use') licenses on three patented pharmaceutical products. ${ }^{142}$ Two of these were ARV treatments: (i) Kaletra (Lopinavir and Ritonavir) (patented in Thailand by Abbott Laboratories) and (ii) Efavirenz (patented in Thailand by Merck). The third was Plavix (clopidogrel), a product used for the treatment of coronary disease, patented in Thailand by Sanofi-Aventis. The licenses will initially be used for the importation of generic products from India, but the government production facility (GPO) plans to initiate local production in the future.

Although the government initially proposed payment of a royalty of $0.5 \%$ to the patent holders, it has indicated (and provided in legislation) that this

137 See Brazil MoH, above n 134, and Joe Cohen, 'Brazil, Thailand Override Big Pharma Patents', Science Mag, 11 May 2007, at 816.

138 See above n 137.

139 Marcia Wonghon, 'Brazil Decides to Make Own AIDS Drug After Talks With Merck Collapse', Brazil Mag, 3 May 2007, available at http://www.brazzilmag.com/content/view/ 8220/54/.

140 See e.g. PEPFAR, Critical Intervention in the Focus Countries: Treatment, at, e.g. Tables 2.8 and 2.9, referring, inter alia, to generic versions of Efavirenz, http://www.pepfar.gov/ documents/organization/81024.pdf.

141 A comprehensive description of Thailand's public health approach to the provision of medicines can be found at Ministry of Public Health and National Health Security Office, Thailand, Facts and Evidences on the 10 Burning Issues Related to the Government Use of Patents on Three Patented Essential Drugs in Thailand, February 2007, ISBN 978-97494591-5-7 [hereinafter the 'Thai White Paper'].

142 Documents evidencing the grants of the compulsory license are attached to the Thai White Paper, above n 141. 
rate remains open to further negotiation and review. The Thai government did not attempt to negotiate voluntary licenses with the patent holders immediately prior to issuing these licenses, but it had previously and unsuccessfully attempted to negotiate price reductions from suppliers over a prolonged period of time.

When the government issued its public use license for Efavirenz, Merck's price was approximately double that of the Indian generic price. Merck later offered to reduce its price for Efavirenz to about $20 \%$ above the Indian generic price. ${ }^{143}$ The Thai authorities expect to reduce the price of purchasing Kaletra to about $20 \%$ of Abbott Laboratories' current price. The government initially indicated that it expected to reduce its costs for clopidogrel (Plavix) by a factor of $10 .^{144}$

The authorities stress that the 'government use' licenses issued for its public health sector will not be used to supply the comparatively small segment of the 'private' commercial pharmaceuticals market, where products are sold at the patentee's prices. Spokesmen for the Health Ministry have publicly declared at several conferences that their goal was to move the pharmaceutical companies from a 'low volume-high margin' pricing strategy to a 'high volume-low margin' alternative approach.

Because Thailand contracted for several months supply of Efavirenz from an Indian generic supplier, the government has not yet considered it necessary to make a decision regarding future purchases from Merck at its reduced offer price. While the authorities continued to hold discussions with Abbott Laboratories and Sanofi-Aventis, it was reported on 21 August 2007, that the Ministry of Public Health had placed an order with an Indian generic producer for two million clopidogrel tablets at a price of $1.01 \mathrm{Baht} /$ tablet, as compared with a price of 70 Baht/tablet paid for Plavix. ${ }^{145}$

Meanwhile, Abbott Laboratories has withdrawn a number of applications for regulatory approval of drugs that were pending at the time the government use license on Kaletra was issued.

\section{Foreign reaction}

The multinational pharmaceutical companies affected by the Brazil and Thailand compulsory licensing decisions claim that these decisions will have a negative effect on research and development for new medicines and have strongly condemned them. ${ }^{146}$ Pharmaceutical industry groups, and more

143 Ibid, at 29 and Document 21 (Merck Press Release).

144 Thai White Paper, above n 141, at 14-15.

145 Theerawut Sathitphattarakul and Apiradee Treerutkuarkul, 'Govt buys heart drug from India', Bangkok Post, 23 August 2007.

146 See e.g. Nicholas Zamiska, 'Abbott Escalates Thai Patent Rift, Firm Pulls Plans to Offer New Drugs in Spat with Regime', Wall St F, 14 March 2007; Merck \& Co, Inc. Statement on Brazilian Government's Decision To Issue Compulsory License for STOCRIN ${ }^{\mathrm{TM}}$, 4 May 2007, available at <http://http://www.merck.com/newsroom/press_releases/corporate/ 2007_0504.html. 
broadly based industry chambers of commerce, have likewise criticized these developments. ${ }^{147}$ On 1 September 2007, it was reported that Sanofi-Aventis, holder of the Thai patent on clopidogrel/Plavix, had threatened to sue Emcure Pharmaceuticals, the Indian company that was awarded a purchase contract by the Thai Ministry of Public Health, if it imported generic clopidogrel into Thailand. ${ }^{148}$

At least in the case of Thailand, the reaction by US government authorities was initially somewhat conciliatory. United States Trade Representative (USTR) Susan Schwab assured a substantial number of concerned members of Congress that the actions taken by the government of Thailand appeared to fall within WTO rules, and that USTR was not directly involved in addressing this situation. Nevertheless, USTR placed Thailand under 2007 Special 301 'Priority Watch List' surveillance, stating:

[I]n Thailand, in late 2006 and early 2007, there were further indications of a weakening of respect for patents, as the Thai Government announced decisions to issue compulsory licenses for several patented pharmaceutical products. While the United States acknowledges a country's ability to issue such licenses in accordance with WTO rules, the lack of transparency and due process exhibited in Thailand represents a serious concern. These actions have compounded previously expressed concerns such as delay in the granting of patents and weak protection against unfair commercial use for data generated to obtain marketing approval. ${ }^{149}$

It should be noted that Article 23 of the WTO Dispute Settlement Understanding obliges Members to seek redress for alleged violations of the WTO Agreement through specified multilateral venues and procedures. ${ }^{150}$ Though perhaps slower off the mark than USTR, the European Commission launched a high-pressure campaign aimed at the Thai government on behalf of Sanofi-Aventis with a letter dated 10 July 2007, from Trade Commissioner Peter Mandelson to Thailand's Minister of Commerce, Krirk-krai Jirapaet. ${ }^{151}$ This letter was written just as the European Parliament was debating whether to ratify the Amendment, and after it had already made clear to the Trade Commissioner that the Parliament supported Thailand's

${ }^{147}$ See e.g. PhRMA Press Release, Protecting Patent Rights in Thailand, 1 December 2006; PhRMA Press Release, PhRMA Response to 2007 Special 301 Report, 30 April 2007, available at http://phrma.org; US Chamber of Commerce Press Statement, Brazil Takes Major Step Backward on Intellectual Property Rights, Says U.S. Chamber, 4 May 2007.

148 'New challenge to Thai drug licensing (Breaking News)', Bangkok Post, 1 September 2007.

149 USTR 2007 Special 301 Report, available at <http://www.ustr.gov/assets/Document Library/Reports_Publications/2007/2007_Special_301_Review/ass et_upload_file230_11122. pdf $>$.

150 See United States-Sections 301-310 of the Trade Act of 1974, Report of the Panel, WT/ DS152/R, 22 December 1999.

151 Official exchange of correspondence between European Commmission and Thai officials in authors' files. Reported on in, e.g. David Cronin, EU Split Arises Over Thai Effort To Obtain Cheaper Patented Drugs, IP-Watch, 5 September 2007. 
compulsory licensing efforts. On July 12, the European Parliament, with the Thai licenses very much in mind, adopted a Resolution 'Encourag[ing] the developing countries to use all means available to them under the TRIPS Agreement, such as compulsory licences and the mechanism provided by Article 30 thereof' ${ }^{152}$ Parliament delayed ratification of the Amendment pending further assurances from the Commission concerning its future policies on access to medicine issues in developing countries.

For the record, Mandelson stated that Thailand's posture '... risks forcing more drug companies to abandon their patents and could lead to the isolation of Thailand from the global biotechnology investment community'. ${ }^{153}$ In reality, no drug company has abandoned a patent in Thailand. In fact, Sanofi-Aventis has announced plans to sue an Indian producer on the basis of its Thai clopidogrel patent. Nevertheless, the statement was followed by a not-so-veiled threat of economic reprisal through the withholding of foreign investment.

Mandelson further stated that 'Neither the TRIPS Agreement nor the Doha Declaration appear to justify a systematic policy of applying compulsory licenses wherever medicines exceed certain prices'. ${ }^{154}$ As the Thai Minister of Public Health pointed out in reply, Thailand had not adopted such a policy, ${ }^{155}$ nor was it likely that Commissioner Mandelson had reason to believe that it had. Nonetheless, from the standpoint of WTO law, Mandelson misstates the rules. Article 31 of the TRIPS Agreement does not limit the grounds on which compulsory licenses may be issued, and Paragraph $5(\mathrm{~b})$ of the Doha Declaration states that 'Each Member has the right to grant compulsory licences and the freedom to determine the grounds upon which such licences are granted'. ${ }^{156}$

Every country in the EU currently regulates pharmaceutical prices. There is not a significant difference between mandating the price of a drug and telling a company that if its prices exceed a certain level, an alternative supplier will be authorized. If a pharmaceutical company doing business in

${ }^{152}$ European Parliament resolution of 12 July 2007 on the TRIPS Agreement and access to medicines, P6_TA-PROV(2007)0353, para 9, available at $<$ http://www.europarl.europa.eu/ sides/getDoc.do? Type $=$ TA\&Reference $=$ P6-TA-2007-0353\&language $=\mathrm{EN}>$ [hereinafter EP Resolution of 12 July 2007].

153 See above n 151.

154 Letter from Peter Mandelson, above n 151.

155 Letter from Dr Mongkol Na Songkhla, Thailand Ministery of Public Health, to Peter Mandelson, dated 21 August 2007.

${ }^{156}$ Doha Declaration, above n 33, para 5(b). See also ibid, para 4, which provides: We agree that the TRIPS Agreement does not and should not prevent Members from taking measures to protect public health. Accordingly, while reiterating our commitment to the TRIPS Agreement, we affirm that the Agreement can and should be interpreted and implemented in a manner supportive of WTO Members' right to protect public health and, in particular, to promote access to medicines for all. [Emphasis added] 
Europe refuses to supply a patented product at the price deemed appropriate by the government, a compulsory license - as recently evidenced by events in Italy-may issue. ${ }^{157}$

After Commissioner Mandelson's letter became the subject of public debate, another unidentified 'Commission official handling trade issues' reportedly went further to say that while Thailand's first two compulsory licenses on AIDS drugs 'meets anyone's understanding of an urgent public health issue ... Something like heart disease, perhaps does not meet the criteria'. ${ }^{158}$

The suggestion that treatments for heart disease exceed a state's right to grant a compulsory license conflicts directly with the TRIPS Agreement, the Doha Declaration and the August 30 Decision. Given that the EU Regulation implementing the Waiver Decision, and now the Amendment, which is the subject of Parliamentary consideration, expressly applies to 'any' medicine, it may be that the Commission does not share the Parliamentary and Council interpretation of the Waiver Decision as reflected in the Regulation.

\section{Concluding observations}

The highly visible compulsory licenses on patented medicines issued by Brazil and Thailand may represent a turning point in government willingness to exercise flexibilities that the TRIPS Agreement permits and the Doha Declaration reconfirmed. Prior to these actions, developing country governments had been reluctant to make use of these TRIPS flexibilities, presumably out of concern for adverse reaction from major trading partners, and possibly because they did not wish to appear hostile to foreign direct investment.

Despite the fact that pressures on Thailand from both the US and the EU have been increasing, there is a wider public understanding of the rights of Members under the TRIPS Agreement today than was the case in 1997, when these same powers wrongfully condemned South Africa for public health legislation alleged to have been inconsistent with the TRIPS Agreement. Media outlets, supportive of Pharma's tactics, can go only so far in misrepresenting international legal rules before the critical reaction from NGOs reveals their position to be political, not legal in nature. Moreover, Thailand has stated its intention to bring a claim for WTO dispute settlement if trade sanctions are wrongfully imposed. In that event, there is little doubt that Thailand would win a dispute settlement action based on the TRIPS-compliance of its government use licensing.

157 See above n 86 and accompanying text. For the problems with price regulation in the EU, see Klaus Stegeman, 'International Price Discrimination and Market Segmentation for Patented Pharmaceuticals in the EU-A Social Welfare Analysis', in Intellectual Property, Public Policy, and International Trade, above n 85, at 145-68.

${ }^{158}$ David Cronin, EU Split Arises Over Thai Effort To Obtain Cheaper Patented Drugs, IP-Watch, 5 September 2007. 
If the actions by Brazil and Thailand are successfully maintained, they may improve the climate for use of the Article 31bis Amendment. ${ }^{159}$ If these initiatives also stimulate other pharmaceutical stakeholders to review their pricing strategies in the developing countries, the end result could lead to a win-win approach for all sides, as discussed further.

\section{The untested alternative route under Article $\mathbf{3 0}$}

The pending Amendment expressly provides that WTO Members are not precluded from exercising other rights under the TRIPS Agreement. ${ }^{160}$ Therefore, if production and export by third parties of patented medicines were deemed permissible under Article 30, which deals with exceptions rather than compulsory licensing, ${ }^{161}$ this possibility has not been foreclosed by the Amendment.

Because exports of patented products under a compulsory license to assist another country lacking manufacturing capacity inflict no harm to the patentee in the former's domestic market, a case can be made for invoking the exceptions clause of Article 30 rather than the provisions of Article 31. This begs the question of the patent holder's expectations in the export market, which may be offset by the importing country's particular circumstances and WTO-consistent legal policies. There are, however, countervailing technical arguments that appeared to have been strengthened by the WTO panel's narrow interpretation of Article 30 in the Canadian Generic Pharmaceuticals case of $1999 .{ }^{162}$

That decision, which elicited considerable academic criticism at the time, ${ }^{163}$ preceded the Doha Declaration on TRIPS and Public Health in 2001. The Declaration, in turn, so emphatically reconfirmed the flexibilities in TRIPS pertaining to public health that it necessarily cast further doubt on the reasoning of the panel in the Canadian Generics case, even with regard to the dispute over the Bolar-type legislation specifically at issue in that context. More recently, a thorough study of Article 30 has further put in question the Panel's reasoning in that case and advanced new arguments

${ }^{159}$ But see the efforts to abolish compulsory licenses in Kenya, which were barely thwarted on 14 September 2007. Paul Carwood, Kenya Rejects Bid to Remove Governmental Compulsory Licensing Flexibilities, IP Watch, 14 September 2007.

160 See Para 5, Article 31bis, above n 37.

${ }^{161}$ See above nn 56-61. See also Christine Godt, 'The So-Called "Waiver Compromise" of Doha and Hong Kong: About Contested Concepts of the Nature of the International Intellectual Property System', in International Intellectual Property, Public Policy, and International Trade, above $\mathrm{n}$ 85, at 201, 209-210, 227-28 (stressing legitimacy of 'controlled extraterritorial effects' under TRIPS Articles 7-8, 30).

162 Canada-Patent Protection of Pharmaceutical Products, WTO Doc. WT/DS1141R (adopted 7 April 2000).

163 See e.g. Robert L. Howse, 'The Canadian Generic Medicines Panel-A Dangerous Precedent in Dangerous Times', 3 J World Intell Prop 495 (2000). 
supporting the use of Article 30 to achieve the goals of pending Article 31 bis without the complications under review in this article. ${ }^{164}$

As discussed further, the authors (along with many NGOs) view this route as an option that governments may wish to consider. In this connection, the European Parliament has recently approved a resolution asking the Commission to respect EU Member States leeway to pursue an Article 30 alternative solution, if they choose to do so, even after eventual ratification of Article 31bis. ${ }^{165}$

In any event, the Amendment makes it clear that countries are not precluded from exporting under compulsory licenses within the otherwise applicable limitations of Article 31(f) (i.e. less than a predominant part of production), without resort to the special legal machinery envisioned in the Amendment. The continuing applicability of Article 30 also permits exports to countries that are not members of the WTO, including a number of the poor countries of the world that may particularly need to import medicines under compulsory licenses. There is no reason why an exporting WTO Member cannot extend the availability of the solution to an importing non-member as a limited exception to the rights of the patent holder in the exporting country, especially if the importing non-member provides a diplomatic representation that it will abide by the conditions of the Amendment. Indeed, several WTO Members have already implemented this option for non-members of the WTO. ${ }^{166}$

\section{E. Multilateral negotiations on a substantive patent law treaty (SPLT)}

As previously reported, India recently undertook the arduous task of conforming its patent law to the norms of the TRIPS Agreement, a process that has generated much controversy and still uncertain results. Like all developing countries, India had to reconcile the international minimum standards of intellectual property protection with its own cultural and technical assets, with a view to minimizing the social costs and maximizing the potential gains in trade. ${ }^{167}$ Making this assessment with regard to the needs of India's public health sector proved especially daunting because of tensions between the pro-competitive outlook of its robust generic pharmaceutical industry and the more protectionist views of its growing research-based pharmaceutical sector.

This legislative exercise has produced a novel and ingenious mix of domestic and international provisions, whose economic effects remain to be seen and whose legal validity was recently challenged by major

${ }^{164}$ See Christopher Garrison, Exceptions to Patent Rights in Developing Countries, UNCTADICTSD Issue Paper No. 17 (2006).

165 See EP Resolution of 12 July 2007, above n 152, para 10.

166 See e.g. implementing legislation of Canada, the EU and Norway.

167 See generally, J.H. Reichman, 'From Free Riders to Fair Followers: Global Competition under the TRIPS Agreement', 29 N Y U J Int'1 L \& Pol 11 (1997). 
pharmaceutical companies in the Novartis case and questioned by the US Trade Representative. ${ }^{168}$ In this case, Novartis challenged Section 3(d) of the amended India Patents Act as being inconsistent with Article 27.1 of the TRIPS Agreement and the Indian Constitution ${ }^{169}$ because it discriminated against the pharmaceutical sector. Amended Section 3(d) denies patentability for claims of modifications to previously known pharmaceutical substances that do not demonstrate significant enhancement in 'efficacy'. In layman's terms, to obtain a patent on a modification to an already known product, under amended Section 3(d), the applicant must show that the change improves the treatment. This is hardly a startling proposition. ${ }^{170}$

The Madras High Court rejected Novartis' claim on the grounds that India, following the British Commonwealth constitutional model, does not permit the direct effect of treaties (such as the WTO and TRIPS Agreements). ${ }^{171}$ Novartis thus lacked standing under Indian law to challenge the TRIPS consistency of the legislation. The Court also rejected Novartis' claim that the Amended Patents Act provision was unconstitutional because it delegated overly broad authority to the Patent Office to determine the meaning of 'efficacy.' It observed that efficacy is a well-understood concept in the field of pharmaceuticals, that it would be exceedingly difficult to prescribe a fixed meaning of that concept applicable across all pharmaceutical inventions, and that the development of standards to assess efficacy was perfectly consistent with the role of the Patent Office as contemplated by the Indian Parliament.

Subsequent to the decision, the Chairman of Novartis announced that the company would redirect its research and development program away from India to more receptive environments. ${ }^{172}$ Whether the EU, Switzerland or the United States will eventually challenge India's patent law before the WTO remains to be seen, once the Indian courts apply its provisions to the patents emerging from the mailbox. In any event, because India remains the largest alternative supplier of generic drugs to the developing world market at the present time, the results of its legislative balancing act at home could affect the availability and affordability of essential medicines in all developing countries for a considerable period of time. ${ }^{173}$

168 See e.g. Janis M. Mueller, 'Taking TRIPS to India-Novartis, Patent Law, and Access to Medicines', 356 New England J Medicine 541; Janis M. Mueller, The Tiger Awakens, above n 28.

169 See Novartis v India, W.P. Nos. 24759 of 2006 and 24760 of 2006, High Court of Madras (India), decided 6 August 2007.

170 It is worth noting that the US PTO applied an efficacy test to claimed pharmaceutical inventions prior to the decision by the Federal Circuit in In re Brana, 51 F.3d 1560 (Fed. Cir 1995).

${ }^{171}$ Novartis v India above n 169.

172 Andrew Jack, Novartis to move Indian REDD, FT.com, 22 August 2007.

173 The legal challenge to India's statute mounted by Novartis is reminiscent of the unsuccessful effort by major originator pharmaceutical companies to derail South Africa's progressive Medicines and Related Substances Control Amendment Act of 1997. The South Africa case 
The highly publicized debate about domestic patent reform in India is thus emblematic of a similar, if quieter, process that has been taking place in all developing countries (except for the LDCs) over the past few years. How all these countries implement the TRIPS standards into their domestic laws will determine the balance between private incentives to innovate and the public interest in free competition, with serious short- and medium-term implications for economic growth and development. This process manifestly requires time, capacity building and cumulative technical expertise, as well as a suitable business infrastructure, to succeed in the end. ${ }^{174}$

Yet, time and patience is exactly what the OECD countries seem determined not to grant the developing world in this respect. On the contrary, the OECD countries, grouped within WIPO's Standing Committee on the Law of Patents (SCP), have pressed the developing countries to adhere to a draft SPLT. ${ }^{175}$ This proposed treaty represents an attempt 'to pursue a "deep harmonization" of both the law and practice' concerning not just the drafting, filing and examination of patent applications, but also cornerstone requirements of patentability, such as novelty, nonobviousness, sufficiency of description, and drafting and interpretation of claims. ${ }^{176}$ Notably, through the efforts of the so-called Group of Friends of Development, ${ }^{177}$ this initiative is also being tested against the drive for a more

riveted public attention because it was wrongfully pursued under the TRIPS Agreement in the face of a mushrooming HIV-AIDS pandemic, and it appeared to show a blatant disregard for the public health consequences of blindly pursuing enforcement of international trade and patent rules (without legal justification).

174 See e.g. Maskus and Reichman, 'The Globalization of Private Knowledge Goods', above n 7.

175 See Standing Committee on the Law of Patents (SCP), Draft Substantive Patent Law Treaty (SPLT), 10th Sess., 10-14 May 2004, WIPO doc. SCP/10/2, 30 September 2003; Standing Committee on the Law of Patents (SCP), Information on Certain Recent Developments in Relation to the Draft Substantive Patent Law Treaty (SPLT), 10th Sess., 10-14 May 2004, WIPO doc. SCP/10/8, 17 March 2004; Standing Committee on the Law of Patents, (SCP), Report, 10th Sess., 10-14 May 2004, WIPO doc. SCP/10/11, 1 June 2005.

176 Karen M. Hauda, 'The Role of the United States in World-Wide Protection of Industrial Property', in The Future of Intellectual Property in the Global Market of the Information Society 91, 97 (2003) ('This approach was adopted in an attempt to avoid the controversial hurdles to agreement that were found in the past.'). See also Philippe Baechtold, The Future Role of WIPO, in the Area of Industrial Property, ibid at 139, 142-3 (highlighting the need to cover other topics such as patentable subject matter, the requirement of technical character of an invention, exceptions from patentability, novelty grace period and issue of equivalents). All of these issues constitute 'flexibilities' under the TRIPS Agreement, of which compulsory licensing is but one very important component. See generally, Carlos Correa, Trade-Related Aspects of Intellectual Property Rights: A Commentary On The Trips Agreement (Oxford University Press 2007).

177 On 4 October 2004, the General Assembly of the World Intellectual Property Organization agreed to adopt a proposal presented by the Group of Friends of Development (namely: Argentina and Brazil), for the establishment of a Development Agenda for WIPO, Doc. WO/ GA/31/11. Since then, many other proposals have been presented and discussed, see e.g. Provisional Committee on Proposals Related to a WIPO Development Agenda, Proposal for a Decision of the PCDA on the Establishment of a WIPO Development Agenda, PCDA/2/2 
development-friendly agenda at WIPO, with a view to ensuring consideration of the needs of all nations, whatever their technological capacities may be. ${ }^{178}$

In a forthcoming article, Prof. Reichman and Prof. Cooper Dreyfuss demonstrate the likely adverse affects a further round of patent harmonization would have on the developing countries. ${ }^{179}$ These include:

- Erosion of whatever flexibilities these countries still retain under the TRIPS Agreement.

- The risk that virtually every pro-competitive option still left open-from exceptions to patentability, limitations on exclusive rights, and the possibility of imposing compulsory licenses-would shrink or disappear. $^{180}$

They conclude that what developing countries most need is a 'period of calm and stability in which to devise intellectual property strategies consistent with both the TRIPS Agreement and the needs of their own emerging national and regional systems of innovation... They cannot succeed if, at the international level, a new round of multilateral intellectual property negotiations threatens to raise the technological ladder once again before they even get a solid foot hold on it.'181

Reichman and Dreyfuss also argue that a premature patent harmonization exercise of this kind could boomerang against the very developed countries that are pushing it forward at WIPO. ${ }^{182}$ They point out that there is no consensus on how the patent law should address new technologies, and that the US Supreme Court has radically been reshaping the domestic patent system. ${ }^{183}$ The European Patent Office, which has increasingly experimented with new approaches to new technologies that deviate from US practice, recently issued its own cautionary views on the future of patent law. ${ }^{184}$

(22 June 2006), available at http:/www.stakeholderforum.org/22june2006.html. See also James Boyle, 'A Manifesto on WIPO and the Future of Intellectual Property', 2004 Duke L \& Tech Rev 9 (2004).

178 See generally, papers presented at the World Intellectual Property Organization's Open Forum on the Draft Substantive Patent Law Treaty (SPLT), International Conference Center (ICC), Geneva, Switzerland, 1-3 March 2006 [hereinafter WIPO Open Forum], available at http://www.wipo.int/meetings/en/2006/scp_of_ge_06/scp_of_ge_06_inf1.html.

179 Jerome H. Reichman and Rochelle Cooper Dreyfuss, 'Harmonization without Consensus: Critical Reflections on Drafting a Substantive Patent Law Treaty', 57 Duke L J 85 (2007).

180 Ibid.

181 Reichman and Cooper Dreyfuss, above n 179. See also Maskus and Reichman, above n 7; Joseph Stiglitz, The Economic Foundations of Intellectual Property, Frei Lecture, Duke University School of Law, 16 February 2007, available at http://www.law.duke.edu/webcast/; Margaret Chon, above n 11 .

182 Reichman and Cooper Dreyfuss, above n 179.

183 See e.g. E-Bay v MercExchange, 126 Sup. Ct. 1837 (2006); Merck v Integra Lifeseciences, 125 S. Ct. 2372 (2005), and KSR v Teleflex, 127 Sup. Ct. 1727 (2007).

184 EPO, The Future of Patent Law (2007). 
While we lack space to explore these matters in depth, we reiterate the view that 'any attempt to achieve deep harmonization of world patent law at the present time, such as that contemplated by the SPLT, is premature'. ${ }^{185}$ What is needed, instead, is a period of experimentation in which different countries at different levels of development seek to adapt the traditional patent system to their own needs, taking into account the challenges of new technologies and of the emerging transnational system of innovation as a whole that TRIPS brought into existence. ${ }^{186}$

\section{F. The problem of the free trade agreements}

The originator pharmaceutical industry based in OECD countries was not satisfied with the terms of the TRIPS Agreement negotiated during the Uruguay Round. Moreover, increased protection for this industry is not a realistic negotiating objective at the WTO, at least under present circumstances, and further harmonization under the SPLT at WIPO has encountered mounting opposition.

As a 'second best' solution, US pharmaceutical originators (represented by PhRMA) have intensively lobbied USTR and other parts of the US government (including Congress) to incorporate higher levels of industry protection in bilateral and regional free-trade agreements (FTAs). ${ }^{187}$ The EU originator pharmaceutical companies are similarly lobbying the European Commission and EU institutions (and Member State governments), perhaps so far with somewhat less overall success.

\section{Agreements of the United States}

A modest level of enhanced protection (above that later provided by the TRIPS Agreement) had been incorporated into NAFTA. ${ }^{188}$ However, the trend towards higher levels of protection commenced in earnest with negotiation of an FTA with Jordan in 2001, and has progressed through a series of FTAs with developing and developed countries, including Chile, Australia, Singapore, Morocco, Central America (including Costa Rica, El Salvador, Guatemala, Honduras, Nicaragua and the Dominican Republic) ('CAFTADR'), Bahrain, Oman, and in signed, but not yet ratified, agreements with Panamá, Peru, Colombia and South Korea. ${ }^{189}$

\footnotetext{
185 Reichman and Cooper Dreyfuss, above n 179.

186 See Maskus and Reichman, 'The Globalization of Private Knowledge Goods, above' n 7.

187 For an economic assessment, see Carsten Fink and Patrick Reichenmiller, above n 10. For legal analysis and additional references see Abbott, WTO Medicines Decision, above n 27 at 349 ff and Frederick M. Abbott, Intellectual Property Provisions of Bilateral and Regional Trade Agreements in Light of U.S. Federal Law, UNCTAD - ICTSD Project on IPRs and Sustainable Development, Issue Paper No. 12, February 2006.

188 See e.g. North American Free Trade Agreement (NAFTA) Articles 1709 and 1711, available at http://www.nafta-sec-alena.org.

189 Texts generally available at $<$ http://www.ustr.gov $>$.
} 
Although the patent and pharmaceutical regulatory terms of the FTAs vary with the different agreements, they follow a common template. The main objectives are to:

- extend the scope of patent protection to cover new uses of known compounds, and plants (and, on occasion) animals;

- provide patent term extensions to offset regulatory delay;

- limit the scope of permissible exceptions to patent rights;

- provide fixed periods of marketing exclusivity for a broad class of previously unapproved products, based on submission of regulatory data (especially clinical trial data) or reliance on foreign marketing approval or foreign submission of regulatory data;

- prohibit effective granting of marketing approval by the health regulatory authority during the patent term without the consent or acquiescence of patent holders ('linkage');

- authorize nonviolation nullification or impairment dispute settlement claims;

- prohibit parallel importation (in some cases); and

- limit the grounds for granting compulsory licensing (in higher income countries).

The combined impact of these various restrictive provisions is to significantly strengthen the position of originator-patent holder pharmaceutical enterprises on national markets, and thereby to erect barriers to the introduction of generic pharmaceutical products.

One major concern with several of the foregoing restrictive measures is that they could effectively preclude use of compulsory licensing because they contained no language that expressly avoids this result. Virtually all countries require the public health authority to approve and register a medicine before distribution on the market. The provisions of the FTAs for patent linkage make no provision for registration of generic medicines produced under compulsory licenses, while otherwise requiring the consent of the patent holder for marketing approval. In response to objections from NGOs and members of Congress, USTR appended 'side letters' to the FTAs intended to give the appearance of addressing this problem. But USTR refused to acknowledge that these attachments resulted in any exception to the express terms of the agreements. ${ }^{190}$

Although the EU's pharmaceutical originator enterprises are not direct participants in these FTA negotiations, they remain indirect beneficiaries of their terms once concluded. This result follows from Article 4 of the TRIPS

190 See Abbott, WTO Medicines Decision, above n 27, at 352-3 (discussing USTR's position regarding the legal effect of public health side letters). 
Agreement, which requires the extension of most favored nation (MFN) treatment to all WTO Members. ${ }^{191}$

After the Democratic Party gained control of the Congress beginning in 2007, certain changes were agreed upon between the Executive (represented by USTR) and congressional leaders with respect to signed, but not yet ratified, FTAs (with developing countries). ${ }^{192}$ Although the changes introduced by this agreement undoubtedly represent an improvement over the pre-existing situation, additional obligations have also been proposed that would reduce the magnitude of these changes.

The new template, as reflected in the terms of the amended FTA between the United States and Peru, ${ }^{193}$ introduces an explicit exception from marketing exclusivity with respect to the grant of compulsory licenses. This eliminates the need to rely on the side letters mentioned above, which effectively rewrote and narrowed the Waiver Decision and Amendment Article 31 bis.

The new template removes most of the language providing extraterritorial effect for the submission of regulatory data in the United States (and elsewhere) that pertains to pharmaceutical products, although this effect is retained for agricultural chemicals. The marketing exclusivity provision for pharmaceutical products establishes a presumptive five-year term as the 'reasonable period' of protection, taking into account the nature of the data and the expenditure in creating it. ${ }^{194}$ This leaves room for a reduced period of protection (but also does not expressly incorporate an upper limit on the term of protection). ${ }^{195}$

The marketing exclusivity provision limits the term of protection, for countries which rely on foreign approval, to the term in the country whose approval is relied upon, but only if the relying country approves the application for registration within six months. ${ }^{196}$ Note that for some countries a six-month approval cycle might be unattainable. The text does not expressly limit the marketing exclusivity period in the foreign country. One can

191 TRIPS Agreement, above n 1, Article 4. Regional agreements entered into subsequent to entry into force of the TRIPS Agreement do not enjoy an exclusion from the requirement of extending MFN [pursuant to Article 4(d) of the TRIPS Agreement]. See UNCTAD-ICTSD Resource Book on Trips and Development, above n 1 at 77-82; Abbott, WTO Medicines Decision, above n 27 at 357 (stressing trade barrier effects of intellectual property provisions).

192 See e.g. USTR, Bipartisan Agreement on Trade Policy: Intellectual Property, May 2007, Trade Facts, available at $<$ http://www.ustr.gov $>$.

193 Available at http://www.wto.gov.

194 Ibid.

195 Whether the template allows for 'cost sharing' rather than exclusivity in some circumstances also remains unclear. For the view that 'cost sharing' should have been the preferred approach, see Jerome H. Reichman, 'The International Legal Status of Undisclosed Clinical Trial Data: From Private to Public Goods?', in Negotiating Health-Intellectual Property and Access to Medicines, P. Roffe et al., (eds), (Earthscan 2006), 133-46 [hereinafter Negotiating Health].

196 See above n 193. 
imagine requests to match the foreign exclusivity period, even if this is not expressly required. ${ }^{197}$

The new template makes patent term extension with respect to pharmaceutical products optional for delays based on regulatory approval and patent application approval. ${ }^{198}$ It also adds an obligation to provide preliminary injunctions or equivalent effective provisional measures for claims of infringement covering a patent on an approved pharmaceutical product or its approved method of use. ${ }^{199}$ Given the ambiguity or openended quality of some of the provisions on marketing exclusivity, and the new provisions on remedies, we foresee continuing discussions about the extent to which the FTAs inhibit access to medicines.

\section{Agreements of the European Union}

The EU has nominally adopted a policy of not pursuing pharmaceuticalrelated TRIPS-plus commitments in its negotiations with developing countries, while nonetheless 'free riding' on the pharmaceuticals commitments obtained by the United States. In this sense, further EU negotiations on this topic could be superfluous (at least in so far as the EU and United States are negotiating with the same parties). However, it is not really the case that the EU foregoes additional pharmaceutical-related commitments in its bilateral and regional negotiations. ${ }^{200}$

First, in its proposed Economic Partnership Agreements (EPAs) with the African, Caribbean and Pacific (ACP) countries, the EU is negotiating for adherence to or acceptance of the obligations of the Patent Cooperation Treaty $(P C T)^{201}$ and the Patent Law Treaty (PLT). ${ }^{202}$ These procedural treaties facilitate obtaining patents in the signatory countries. Given the growing number of pharmaceutical patent filings in developing countries,

197 The new template changes the products affected by marketing exclusivity from 'new pharmaceutical product' to 'new chemical entity'. 'New pharmaceutical product' had been further defined to refer to products not previously approved in the national territory, which appeared to require treating products not previously approved only in other countries as 'new'. The new template does not further define 'new chemical entity', providing some discretion as to how that term will be applied. However, because of language in the new template indicating when marketing exclusivity need not be provided, some clarification of the intent of the new terms will be needed.

198 See above n 193.

199 This specific obligation which did not appear previously in the enforcement section of the IP chapter template, is accompanied by a requirement that the patent holder be given adequate notice and sufficient time to bring such an action prior to the marketing of the allegedly infringing product. Note that, in many developing countries, preliminary injunctions can effectively hinder generic producers seeking to enter the market. Moreover, while 'method of use' language was used in the prior template, the context was subtly different which may also raise issues in some legal systems.

200 And this is leaving aside the fact that the EU has required countries joining the Union to accept the full panoply of EU regulations respecting pharmaceuticals, which in some cases (e.g. Hungary) adversely affected local generic producers.

201 Patent Cooperation Treaty, 19 June 1970, 28 UST 7645, 1160 UNTS 231.

202 Patent Law Treaty, 1 June 2000, 39 ILM 1047 (2000). 
this obligation may have a significant impact on the number of patents on pharmaceutical products and processes granted in the ACP countries. At the very least, it affords originators a 30-month priority period during which investors in generic products cannot readily enter local markets, even if no patent applications have been filed. ${ }^{203}$

Second, and more important, the EU is effectively seeking to burden the ACP countries with the duty to implement the terms of its Intellectual Property Enforcement Directive. ${ }^{204}$ One enforcement provision of a draft EPA proposed by the Commission ${ }^{205}$ requires that competent judicial authorities, 'even before the commencement of proceedings on the merits of the case', on the basis of 'reasonably available evidence to support [a patent holder's] claims' '... may 'order prompt and effective provisional measures' '... including 'the physical seizure of the infringing goods, and, in appropriate cases, the materials and implements used in the production and/or distribution of these goods'.

Such a provision, with a low evidentiary standard and lacking a temporal limitation, may have a chilling impact on producers of generic medicines who are threatened with seizure of products and production equipment in advance of a determination as to the validity of the evidence. The seizures could last for an extended duration and cripple the business without any meaningful judicial process. Although the draft EPA text includes language like that used in Article 50 of the TRIPS Agreement, ${ }^{206}$ it goes substantially beyond Article 50, and does not expressly incorporate protections for defendants found in that Article. ${ }^{207}$

There are various other enforcement provisions in the draft EPAs that could undermine the interests of the generics sector in developing countries. ${ }^{208}$ Yet, the European Parliament recently adopted a report on EPAs, which asked the Commission not to include IP provisions that could adversely affect access to essential medicines. ${ }^{209}$

${ }^{203}$ See Maximiliano Santa Cruz S., Intellectual Property Provisions in European Union Trade Agreements, ICTSD Issue Paper No. 20 (2007).

${ }^{204}$ Directive 2004/48/EC of the European Parliament and of the Council of 29 April 2004 on the enforcement of intellectual property rights, OJ L 195/16, 2 June 2004.

205 The authors have received draft texts in confidence from negotiators and do not consider that further identification of source is necessary or appropriate here.

${ }^{206}$ See TRIPS Agreement, above n 1, Article 50.

207 See e.g. ibid, Articles 50.6 and 50.7 .

${ }^{208}$ For example, Article 4 of the EU Enforcement Directive, above n 204, replicated in draft EPAs, provides that: 'Member States shall recognize as persons entitled to seek application of the measures, procedures and remedies referred to in this chapter:...(d) professional defence bodies which are regularly recognized as having a right to represent holders of IPRs, in so far as permitted by and in accordance with the provisions of the applicable law.' Here the EU aims to provide 'friends of Pharma' with an explicit right to initiate legal claims against generic producers seeking entry into the national market.

209 European Parliament resolution of 23 May 2007 on Economic Partnership Agreements (2005/2246(INI)) P6_TA-PROV(2007)0204, at para 45. The European Parliament renewed this request in the resolution adopted on 12 July 2007, above n 152 . 
A developing country that enters into an FTA with the United States and an EPA with the EU along the lines of those currently proposed will be constrained to provide a very strong market dominant position for pharmaceutical originator companies, and thus to create substantial obstacles to the introduction of generic products. In light of the importance of the national implementation process, moreover, it is difficult to assess the full impact of the new US FTA policy until the details are more fully developed and made public. ${ }^{210}$

Nevertheless, we believe that EPAs should refrain from imposing any new intellectual property obligations on APC countries that could affect their public health programs. To this end, the European Parliament has adopted a new resolution expressly calls upon the EC to endorse full implementation in APC countries of the flexibilities set out in the TRIPS Agreement, as recognized in the Doha Declaration 'to promote access to medicines for all'. ${ }^{211}$

\section{G. The World Health Organization's intergovernmental working group on public health, innovation and intellectual property (IGWG)}

Under pressure from developing country governments and NGOs, WHO has initiated a process to assess the global situation concerning public health, innovation and intellectual property, and to recommend an action plan geared to its findings. ${ }^{212}$ Meetings bearing on the Intergovernmental Working Group (IGWG) are taking place in Geneva, and the prospective impact of this ongoing work at the WHO remains hard to predict. Nonetheless, the WHO was absent during the GATT Uruguay Round negotiations, and over the past decade its leadership has played a modest role in global debates concerning intellectual property and access to medicines. That these issues appear to have gained greater prominence in WHO discussions is, therefore, a positive development. ${ }^{213}$

Brazil, Kenya, Thailand and other developing countries have urged the WHO to adopt an action plan that would encourage research and development directed to medicines important for developing countries and that would improve access to medicines for the bulk of the world's population. This plan should embrace not only tropical, neglected or poverty-related

210 The United States government (and the EC in the case of EPAs) may play a substantial role in proposing and reviewing the rules at the local level, which is consistent with US practise concerning oversight of the implementation of FTA obligations.

${ }^{211}$ European Parliament resolution of 12 July 2007 on the TRIPS Agreement and access to medicines, above n 152, para 11.

212 Documents available at http://www.who.int/phi/en/.

${ }^{213}$ However, Eric Stein's seminal article concerning the democratization process at the WHO should provide a note of caution regarding expectations in this regard. See Eric Stein, 'International Integration and Democracy: No Love at First Sight', 95 AJIL 489 (2001). 
diseases, but also diseases common to developing and developed countries, such as cancer and coronary disease. ${ }^{214}$ These demandeurs seek concrete measures for promoting transfer of technology to improve the capacity of poor countries to participate fully in the development and production of medicines.

Recent discussions at IGWG have focused on proposals to re-examine the link between pricing and the cost of $\mathrm{R} \& \mathrm{D}$, with a view to devising workable new models. There is also growing interest in forming patent pools to deal with poverty-related, tropical and neglected diseases, with the participation of public-private partnerships, such as UNITAID.

Although the EU and the United States have participated in these discussions, the EU aims to ensure that the WHO does not become a primary forum for consideration of IP-related issues. ${ }^{215}$ We believe, instead that both intergovernmental organizations have important roles to play in negotiations concerning patents and other intellectual property rights (IPRs), because IPRs affect Member States' abilities to maintain adequate supplies of medicines as a public good. ${ }^{216}$ The WHO is the designated international governance agency for public health. Nothing has so disrupted the national health ministries' traditional roles in this regard as the top-down, private law codifications of IPRs driven through other international forums with little inputs from them.

While the GATT and WTO were conceived to promote reduction of trade barriers and the free flow of goods and services, patents may create trade barriers, even as they provide incentives to innovate and greater certainty for transfers of technology. Because patents impose significant public health costs by fostering high medicines prices, they are no less relevant to the WHO than to the WTO (or WIPO for that matter). OECD countries might accordingly wish to devote more of their efforts at the WHO to developing an IP environment that promotes public health, without unduly dampening $\mathrm{R} \& \mathrm{D}$ incentives, and spend less time engaging in 'damage control' with respect to rules previously negotiated at the WTO and WIPO.

${ }^{214}$ See e.g. Submissions of Brazil, Kenya, Thailand and others regarding 'Elements of a global strategy and plan of action', A/PHI/IGWG/1/5, available at http://www.who.int/phi/en/.

215 See e.g. Comments by the EU, Consultations on 'Elements of a global strategy and plan of action' (A/PHI/IGWG/1/5), 28/02/2007, available at http://www.who.int.

${ }^{216}$ See e.g. Heinz Klug, 'Access to Essential Medicines: Promoting Human Rights Over Free Trade and Intellectual Property Claims', in IP and International Public Goods, above n 7, 481-92. See also Tracy R. Lewis, Jerome H. Reichman and Anthony D. So, 'The Case for Public Funding and Public Oversight of Clinical Trials', Economists' Voice (January 2007), available at www.bepress.com/ev; Gregory Schaffer, 'Recognizing Public Goods in WTO Dispute Settlement', in IP and International Public Goods, above n 7, 884-908; Graeme Dinwoodie and Rochelle Cooper Dreyfuss, 'WTO Dispute Resolution and the Preservation of the Public Domain of Science Under International Law', in IP and International Public Goods, above n 7, 861-883. 


\section{MAKING THE AMENDMENT SYSTEM WORK}

Cumbersome as it may be, the compromise accepted in the Waiver Decision of August 30 and the corresponding Amendment was arguably the best available at the time and better than alternatives then on the table. Without underestimating its formalistic nature and built-in administrative roadblocks, we believe it can be made workable if governments seeking assistance muster the political will and skill to use the system. Countries able to supply the drugs requested must also enact suitable enabling legislation without too many additional limiting wrinkles imposed by special interest lobbying, as occurred in Canada. ${ }^{217}$

In this connection, the Indian enabling legislation appears supportive of the goals behind the Amendment, ${ }^{218}$ which, of course, promotes the interests of its generic producers. The Secretary-General of the Indian Pharmaceutical Alliance is on record as expressing the willingness of his constituency to respond to requests for assistance by other developing countries, and a spokesman for the European generics industry has also expressed interest. ${ }^{219}$ Whether the countries with the greatest capacity will in fact respond depends on a number of imponderables, including the size of the target market, the procurement guarantees and the stability of local conditions at any given time. Nonetheless, given the legal infrastructure and the known capacities and interest of the Indian and European generic companies, prospects for fruitful collaboration seem reasonably promising.

Converting this promise to reality could largely depend on the strategies of the would-be user countries. Aside from major autonomous markets in middle-income countries, such as those of Thailand and Brazil, much could depend on whether the effort to obtain any given drug is initiated by single countries, each going its own way, or by a number of countries willing and able to pool their single compulsory licenses in a consortium that could afford greater buying power and offer suppliers sounder incentives to invest in production.

In what follows, we outline a blueprint for effective implementation based on what the evolving legal infrastructure makes possible. While real-world obstacles abound, our primary task here is to emphasize what could be done with willpower, skill and resources. OECD governments could themselves play a role in transforming possibilities into practice, given the political will to do so.

${ }^{217}$ See above n 101 and accompanying text.

${ }^{218}$ However, this conclusion presupposes suitable Indian implementing regulations, that are yet to be adopted.

${ }^{219}$ See remarks of Greg Perry, Director-General, European Generic Medicines Association, hearing before the European Parliament International Trade Committee, 5 June 2007. The positive views of the Indian generic association were expressed by Dilip Shah, DirectorGeneral of the Indian Pharmaceutical Alliance, inter alia, at a Roundtable on Global Pharmaceutical Regulation held at Florida State University College of Law, 5-7 April 2007. 


\section{A. Goals and limits of compulsory licensing}

Existing WTO jurisprudence suggests that when tensions arise between the Members' efforts to provide domestic public goods, such as public health, and the private rights of patentees, Members should look to both the codified exceptions to those rights under Article 30 and to the broad possibilities for imposing compulsory licenses under Article 31 (and Amendment Article $31 \mathrm{bis}$ ), before invoking still untested claims for waivers under the hardship escape clauses of Articles 7 and $8 .{ }^{220}$ In the public health sector, developing countries resort to compulsory licensing-either by threat or actual imposition - in order to persuade pharmaceutical companies to lower the prices of specific medicines to the point where they become available to mass market consumers in need of them and not just to affluent members of any given community.

Such licenses are a critical tool for promoting effective price negotiations with patent holders and for enabling local production, importation and distribution of patented medicines at affordable prices. ${ }^{221}$ Where local authorities directly undertake the provision of medicines to meet important public health needs, including the HIV/AIDS pandemic, the obligation to match the costs of distribution with available public resources also exerts pressure to issue compulsory licenses. ${ }^{222}$

Between unregulated monopoly pricing, on one hand, and compulsory licensing on the other, there exist intermediate regimes based on price regulation, which are widely practised in OECD countries. An illuminating example is the case of Canada, which moved from a regime of routine compulsory licensing of patented pharmaceuticals to a regime of price controls in 1992. ${ }^{223}$ These price controls help Canada keep the costs of its socialized medicine program within budgetary reach. With some notable exceptions, developing countries have not widely experimented with price controls on essential medicines, an option that might affect the extent to which compulsory licensing was also employed. ${ }^{224}$

When, instead, developing-country governments resort to compulsory licensing (or threats thereof), they typically seek to move the pharmaceutical companies away from a marketing strategy based on 'low-volume, high margin returns' to a strategy based on 'high-volume, low margin returns, ${ }^{, 25}$ which is more characteristic of the generic industries. Given that generic

${ }^{220}$ See e.g. Canada-Patent Protection of Pharmaceutical Products, WTO Doc. WT/DS114/R (adopted 7 April 2000); UNCTAD-ICTSD, Resource Book, above n 1, at 118-33 (discussing TRIPS Articles 7-8).

${ }^{221}$ See e.g. Thai White Paper, above n 141.

222 See above n 130-40 and accompanying text (case of Brazil).

223 See Reichman with Hasenzahl, 'Non-Voluntary Licensing of Patented Inventions: The Canadian Experience, (ICTSD/UNCTAD 2003).

${ }^{224}$ Kevin Outterson, 'Patent Buy-Outs for Global Disease Innovations for Low- and MiddleIncome Countries, 32 Am J Law \& Med 159, 161 (2006).

225 See above text accompanying nn $144-45$. 
industries operating under the latter strategy remain profitable, one may ask why the big pharmaceutical companies do not voluntarily adopt similar pricing strategies on a voluntary basis in developing countries, given that they typically expect to recoup $R \& D$ costs plus the bulk of their profits in OECD markets. ${ }^{226}$

There are different theories to account for this resistance. One is that because a patent monopoly gives control over prices, the lack of competition simply dulls any incentive to price-differentiate. A second theory is that the pharmaceutical companies fear a 'reference pricing backlash', which would occur if low prices in developing countries were used as benchmarks by price regulators in developed countries. ${ }^{227} \mathrm{~A}$ third theory is that selling needed medicines to the affluent at very high prices in developing countries is objectively more profitable than mass-marketing at low prices. A fourth theory is that pharmaceutical companies are concerned that parallel imported, favorably priced medicines would compete with higher priced offerings. ${ }^{228}$ A fifth theory is that all the above four theories play some part in resistance to price discrimination.

Whatever the truth may be, we emphasize that the overall goal in evaluating the pending Amendment to the TRIPS Agreement is the extent to which it can help developing countries shift the patentees' strategy to a 'high volume-low margin' approach without unduly impacting incentives to invest and to innovate. The more that the system as a whole encourages pharmaceutical companies to adopt such a strategy voluntarily without government intervention, the less friction it will generate and the more successful it will be.

Here, however, a cautionary note is in order. The foregoing propositions rest on the premise that originator pharmaceutical companies typically recoup their $\mathrm{R} \& \mathrm{D}$ costs plus reasonable profits in OECD markets. ${ }^{229}$ So long as this premise holds, experts in the field maintain that developing country governments that paid these companies their marginal costs of production plus a 5\% royalty would normally be providing generous compensation under either a price regulation scheme or a compulsory license. ${ }^{230}$

${ }^{226}$ See e.g. Outterson, above n 224; Letter from Al Engleberg (on file with the authors).

227 See e.g. Patricia M. Danzon and Adrian Towse, 'Theory and Implementation of Differential Pricing for Pharmaceuticals', in IP and International Public Goods, above n 7 at 425-56.

${ }^{228}$ See e.g. Harvey E. Bale Jr, 'The Conflicts Between Parallel Trade and Product Access and Innovation: The Case of Pharmaceuticals', 1 J Int'l Econ L 637 (1998); see also Klaus Stegman, above n 157 (discussing problems of imperfect market segmentation in EU).

229 The authors do not imply that originator practices in areas such as marketing and executive compensation are presently appropriate and reasonable, but rather they indicate a premise for discussion. See e.g. Carsten Fink, 'Comment', in International Intellectual Property, Public Policy, and International Trade, above n 85, at 169, 171 (noting high marketing expenditures of US industry).

${ }^{230}$ See e.g. Letter from Al Engleberg, above n 226. 
If, instead, pharmaceutical companies either in OECD countries or elsewhere responded to the TRIPS patent incentives by investing in R\&D that pertained to poverty-related, tropical or neglected diseases of primary concern to developing countries, then resort to compulsory licensing would require a different calculus. These companies would necessarily have to seek returns on investment in the affected countries, and ex post resort to compulsory licensing could skew the ex ante investment calculus that led to medical discoveries in the first place. ${ }^{231}$

In such cases, much obviously depends on the extent to which government funding itself played a role in the $\mathrm{R} \& \mathrm{D}$ efforts and on the pricing strategies voluntarily adopted by the patent holder. We shall return to these considerations later on. Nevertheless, we emphasize that care must be taken to focus on the facts of single cases, with a view to achieving win-win situations for all stakeholders over time, when possible.

\section{B. The high transaction costs of single state action ${ }^{232}$}

Haphazard action by single states seeking to impose compulsory licenses on patented pharmaceuticals is limited by economic, legal and technical factors. While middle-income markets, such as those of Thailand and Brazil, are large enough to warrant investments in the production of generic drugs by potential suppliers, the same cannot be said of most other markets in the developing world. Taken one by one, in other words, problems may arise from a lack of economies of scale and scope.

The costs of uncoordinated legal action by single states seeking compulsory licenses are reinforced by a territorial notion of international patent law and by the independence of patents doctrine. ${ }^{233}$ These principles support the kind of market segmentation in which each new supply problem entails a new cat-and-mouse game between patentees and the local governments. In this game, the patentees are the repeat performers, and their powers are augmented by the limited sources of supply-especially of key active ingredients-within the control of big pharmaceutical companies based in developed countries. As a result, these companies often influence the choice of rules under which specific legal contests will occur and the pace at which ultimate decisions will be made.

\footnotetext{
${ }^{231}$ See e.g. Allan O Sykes, above n 25. See generally Mark Lemley, 'Ex Ante Versus Ex Post Justifications for Intellectual Property', 71 U Chi L Rev 129 (2004).

232 This and the following sections are drawn from Jerome H. Reichman, 'Procuring Essential Medicines Under the Amended TRIPS Provisions: The Prospects for Regional Pharmaceutical Supply Centers', Paper prepared for the Seminar on Intellectual Property Arrangements: Implications for Developing Country Productive Capabilities in the Supply of Essential Medicines, United Nations Conference on Trade and Development (UNCTAD), Palais des Nations, Geneva, Switzerland, 18-20 October 2006.

233 Paris Convention above n 3, Articles 2(1), 4bis(2).
} 
Strategies premised on national action alone could thus entail high transaction costs in overcoming an array of technical legal obstacles, and they could require levels of organizational and administrative skills and drive that are often lacking in smaller developing countries. Given a predictable lack of coordination among developing country governments, moreover, action by single states on a case-by-case approach will remain vulnerable to strong legal and economic pressures by rights holders, in the form of defensive actions to choke off critical sources of supply. Even when single battles are won with regard to a specific medicine needed by any given country, the whole process must then be wound up and started over again for the next drug in the next country, with all the legal, economic, and political costs to be repeated.

This patchwork quilt of territorial measures and countermeasures adds to the transaction costs of all the stakeholders without appreciably stabilizing the chain of supply or ensuring access to essential medicines for citizens in poor countries as a whole. Above all, this strategy does little to increase local capacity to produce essential medicines or to reduce the dependence of poor countries on distant foreign suppliers whose research agendas are overwhelmingly geared to market opportunities in developed countries.

\section{The potential benefits of pooled procurement strategies}

A more promising strategy is to think in regional or sub-regional terms, with a view to standardizing procedures, to lowering the transaction costs of all participating countries, and to stabilizing the availability of medical supplies that all the participating countries are likely to need. On this approach, a group of developing countries interested in price regulation of pharmaceuticals could harmonize and coordinate their policies in this regard. With or without price regulation, a pooled procurement strategy would provide incentives to the originator pharmaceutical companies themselves to become 'low bidders' under supply contracts offered by a centralized procurement authority.

Originator pharmaceutical companies that cooperated with such an authority could preserve market share and benefit from economies of scale and scope. When such cooperation was lacking, however, a centralized procurement authority could offer attractive investment opportunities to prospective generic suppliers who could gear production to the larger market that cumulative or pooled compulsory licenses made available.

A pooled procurement strategy would also greatly enhance the procurement agency's opportunities to stimulate direct investment in local production facilities within the region and to obtain support for training and research to enhance that region's own capabilities. Technical assistance of this kind could become particularly effective if developed country governments subscribed to a proposal to 'buy out' the rights to supply 
developing country markets from the pharmaceutical companies themselves; ${ }^{234}$ pursued the establishment of essential medicines patent pools that would offer low (or no) cost production licenses; ${ }^{235}$ or otherwise persuaded patent holders to permit the use of their technologies on preferential terms in developing country markets. ${ }^{236}$

Ideally, a pooled procurement strategy, operating under the facilitations of Amendment Article 31bis, would offer the greatest benefits to a large number of cooperating countries, half of which were LDCs. This model is particularly suited to conditions in Africa. As explained subsequently, moreover, tangible benefits could nonetheless arise from much smaller arrangements between two or three countries, and even when none of the participating countries were LDCs.

\section{A large regional model with many LDCs}

Consider the possibilities that might arise if 12 African countries formed a loose trade association to qualify under Article 31 bis (3), in which at least six of the participating countries were LDCs. Assume further that these countries established a Regional Pharmaceutical Supply Center (RPSC), which could organize the procurement of pharmaceuticals needed to fulfill the demand created by the emission of as many as twelve pooled compulsory licenses by all the participating states.

The RPSC would proceed to tender offers seeking to fulfill these needs as agents of the governments emitting the compulsory licenses. In executing its mandate, the regional authority may first seek to meet its needs through voluntary purchases of genuine goods from authorized distributors operating within the region, on the condition that such providers made their products available at acceptable, negotiated prices, notwithstanding any patents they possessed. The regional entity, acting on behalf of its buyer governments,

234 See K. Outterson, above n 224, at 171-73.

235 See e.g. various proposals by James Love, including Proposal for Patent Pool for Essential Medicines (PPEM), Addis Ababa-3 March 2005, available at http://www.cptech.org/cm/ addisababa03032005.html. See also Anthony D. So, 'Enabling Conditions for the Scientific Commons', presented at the conference, Technology Development in the Life Sciences: Intellectual Property and Public Investment in Pharmaceuticals and Agriculture/, hosted by the Program on Science, Technology and Global Development, The Earth Institute at Columbia University (20-21 May 2004; New York City). Available at: www.earthinstitute. columbia.edu/cgsd/events/documents/so.ppt.

236 The concept of territorial segmentation of patent rights was strongly advocated by the late Prof. Jean Lanjouw in various papers (e.g. J. O. Lanjouw, Beyond TRIPS: A New Global Patent Regime, Policy Brief No. 3, The Center for Global Development, July 2002, at http:// www.cgdev.org/fellows/lanjouw.html; J. O. Lanjouw, 'A Patent Policy for Global Diseases: US and International Legal Issues', 16 Harv J L \& Tech, 86 (2002); J. O. Lanjouw, A Patent Proposal for Global Diseases, Policy Brief No. 84, The Brookings Institution, June 2001; and J. O. Lanjouw, Intellectual Property and the Availability of Pharmaceuticals in Poor Countries, Center for Global Development Working Paper No. 5, April 2002), and has since found its way into practical application by institutions such as the Drugs for Neglected Diseases initiative (DNDi), in licensing arrangements with originator enterprises. 
could thus conduct price negotiations, with a view to inducing rights holders to become low bidders on the project.

If such a deal were concluded, the rights holders would themselves supply the entire regional market under the auspices of the RPSC at the agreed prices, which would apply market-wide or in negotiated tiers. Such a settlement could envision licensing, technical assistance and the provision of key active ingredients to a local partner, which could obviate the need for imports from beyond the region.

In these negotiations, the patentees know that if no agreement were reached, a supply of generics might otherwise be commissioned from lowcost suppliers elsewhere, say, in India, China or Brazil. The foreign patentee also understands that in dealing positively with the RPSC, it stands to enhance its trademark and to preserve market share in the entire region against future competitors, while still selling at a price sufficiently above marginal costs of production to justify the effort. ${ }^{237}$

Alternatively, the Directors of the RSPC (who could be proxies for the respective health ministries) may offer the foreign originator the possibility of selling the patented products at better than rock bottom prices if it established local production facilities in the region. Here the carrot is that the foreign producer who established a manufacturing foothold in the territory would be rewarded by a more favorable remuneration package and by the prospects of supplying the entire regional market. ${ }^{238}$ If the foreign patentee opts to locate in the region, either directly, or through a local partner, the RSPC obtains a reliable, quality local producer, with the possibility of transfers of technology and know-how over time and of longterm collaboration with the RSPC, which should be of reciprocal interest to all concerned.

However, the sticks under this scenario are that if the foreign patentee declines the invitation either to sell at low prices or to produce locally, despite appropriate incentives, the RSPC can either purchase the needed products abroad, under the compulsory licensing system of Article $31 \mathrm{bis}$, or attempt to entice foreign generic producers in India, China, Brazil and elsewhere, to establish local production facilities in the regional territory under Article 31 bis(3). Here the preferred solution would be to locate such a production facility in a designated LDC territory that need not protect

237 While Pharma enterprises could, in principle, threaten to walk away, as they have in the past, some recent statements by a spokesman for the industry have suggested a more cooperative attitude, with assurances that the companies would not walk away from these markets. See I.P. Watch (2006). This attitude may reflect a more realistic assessment of the potential future value of the African market and of the growing capacity of others to enter it.

238 Cf. James Love, 'Four Practical Measures to Enhance Access to Medical Technologies', in Negotiating Health, above n 195, at 241, 246-7. 
pharmaceuticals until 2016, if technical and logistic barriers can be overcome. $^{239}$

A local producer in such a territory, once it had established WHO-certified quality controls and sufficient manufacturing capacity, could become a formidable supplier of low-cost generics to a large area even without resort to compulsory licenses. In other words, local producers working closely with RSPCs could create in Africa something akin to the highly successful generic production base that was previously developed in India, prior to the TRIPS Agreement of 1994. Given these prospects, moreover, Pharma firms may be more likely to decide that the preservation of future market shares, among other considerations, was a sufficient reason to cooperate with the RSPC and not default a substantial continental market to generic competitors.

\section{A smaller model with or without LDCs}

Although a pooled procurement strategy operating under a large regional model like that just described yields the maximum bargaining clout, much smaller variations on this theme will still give economies of scale and scope that should prove attractive to foreign suppliers and investors. For example, even a three-country model in Africa, where two of the participants were LDCs, could produce considerable bargaining power through pooled compulsory licenses. Under either the large or the small model, drugs shipped into or produced in any one of the participants could be re-exported to all the other participants without additional external compulsory licenses, given the facilitations afforded by pending Article 31 bis to certain regional trade agreements. ${ }^{240}$

If, instead, one looks to a region, such as Latin America, where there are many poor countries but few LDCs, a pooled procurement strategy still makes sense. Three small countries bargaining collectively with either the patentees or potential generic suppliers under the double compulsory licensing system of Article 31 bis could still muster a lot more bargaining power than any of the countries proceeding separately. On this scenario, however, there would exist technical obstacles to re-exporting the products

${ }^{239}$ WTO Ministers agreed in Paragraph 7 of the Doha Declaration that Least Developed Members should not be obligated to implement or apply TRIPS provisions for pharmaceutical product patents or data protection until 1 January 2016. Just as important, they agreed that Least Developed Members already allowing for such protection did not need to 'enforce' such rules until that later date. The TRIPS Council adopted a decision confirming this flexibility. Decision of the Council for TRIPS of 27 June 2002. The WTO General Council added a waiver of Least Developed Members' obligations regarding so-called exclusive marketing rights that might otherwise have been used as a substitute for patent protection to block production, import, and sale of medicines. WTO General Council, WT/L/478, 12 July 2002 Least-Developed Country Members-Obligations Under Article 70.9 of the TRIPS Agreement with Respect to Pharmaceutical Products, Decision of 8 July 2002.

${ }^{240}$ Para 3, Article 31bis, above n 37. 
from one participant to another, so shipments and other procedures would have to be coordinated. ${ }^{241}$

\section{Fulfilling technology transfer obligations under Article 66.2}

If OECD countries supported the initiatives outlined above, they could provide grants, subsidies and tax concessions to pharmaceutical companies that cooperated with Regional Pharmaceutical Supply Centers. In so doing, these countries would be fulfilling their duties to help establish a viable technological base in LDCs under Article 66.2 of the TRIPS Agreement. Of particular interest here is the possibility that the patentees' own governments might become willing to make patented technology available through buy-out, patent pools or arrangements for geographically segmented licensing. ${ }^{242}$

In this connection, the German Development Agency, in cooperation with UNCTAD, UNIDO and DFID, has focused considerable efforts and funds to promote local production in LDCs during the lengthened transitional period that was recently established. The European Parliament has also taken steps to encourage all its Member States to support this initiative, and it has asked the Commission to devise a plan for so doing. ${ }^{243}$

\section{Technical cooperation between developing countries}

The architecture of Article 31bis presupposes that poor countries lacking capacity to manufacture needed medicines under compulsory licenses would seek assistance from developed countries, or at least from large, middleincome developing countries, such as India, China and Brazil. In reality, if efforts to expand local production capabilities succeeded, the number of potential assisting suppliers for any given product could multiply.

Any developing country with the capacity to produce a drug needed by another developing country could come to the assistance of the latter country under the double compulsory licensing system to be established by Article 31 bis. Over time, this network of mutual assistance could grow into a formidable self-help production system, which could exert pressure on patentees everywhere to price discriminate on a 'high-volume-low-margin' basis in developing countries generally.

\section{The overriding importance of stimulating local production}

Disregarding the double compulsory licensing scheme envisioned by Article $31 \mathrm{bis}$, the Ministerial action initiated in 2001 created unique opportunities for establishing local production of pharmaceuticals in LDCs by exempting them from any duty to patent (or enforce patents on) medicines until

\footnotetext{
241 See above nn 108-10 and accompanying text.

242 See above text accompanying nn 234-6.

243 See European Parliament Resolution of 12 July 2007, above n 44, paras 3-6.
} 
2016. ${ }^{244}$ As the German Development Agency has clearly recognized, this temporal window of opportunity makes it possible to recreate, on the territory of willing LDCs, the kind of generic pharmaceutical production base that was fostered in India, over a much longer period of time. Given the flexibilities sanctioned by TRIPS, Doha and the post-Doha regimes, moreover, the emergence of growing capacities in these countries (and in other cooperating developing countries) could be pooled and focused on spreading supplies of generic substitutes throughout the developing world at affordable prices.

Of course, doubters will argue that LDCs in Africa or elsewhere lack comparative advantages in this area, and would likely require substantial external assistance, which is correct. But this view overlooks the need for a certain level of autonomy in maintaining the supply of public health as a public good that all governments must address. The negative view also ignores the potential comparative advantages that LDCs in Africa and elsewhere might eventually derive from stores of biogenetic diversity and traditional knowledge, once a viable technological base was established. ${ }^{245}$ If the European Commission helped to enlarge the German initiative to the point where promoting local production in LDCs became a Community-wide commitment, ${ }^{246}$ the prospects for changing the facts on the ground during the LDC window of opportunity (at least until 2016) would be endless.

In this connection, we stress that potential generic manufacturers locating in the LDCs do not need any compulsory licenses at all to operate until 2016. Moreover, through buyouts, patent pools or similar arrangements, willing governments - or the Commission — could indemnify originator pharmaceutical companies for lost $R \& D$ recoveries that resulted from establishing production in poor countries and from assisting other such countries to obtain the relevant medicines. Precisely because pharmaceutical companies currently do not look to these markets for recuperating research expenditures on global diseases, costs of buy outs or pooling arrangements would be low and risks are minimized. ${ }^{247}$

${ }^{244}$ Doha Declaration, above n 33, para 7, and implementing action by Council for TRIPS and General Council, (Decision of the Council for TRIPS of 27 June 2002, and Decision of the General Council of 8 July 2002, available at http://www.wto.org). See note 239 above and also above $\mathrm{n} 27$ and accompanying text.

${ }^{245}$ See e.g. Graham Dutfield, 'Legal and Economic Aspects of Traditional Knowledge', in IP and International Public Goods, above n 7, at 495-520; Jerome H. Reichman and Tracy Lewis, 'Using Liability Rules to Stimulate Local Innovation in Developing Countries: Application to Traditional Knowledge', in International Public Goods, above n 7, at 337-66; Emanuela Arezzo, 'Struggling Around the "Natural" Divide: The Protection of Tangible and Intangible Indigenous Property', 25 Cardozo Arts \& Ent L J 367-415 (2007).

246 See European Parliament 12 July 2007 Resolution, above n 44, to this effect.

247 See K. Outterson, above n 224, at 171, (noting that under a buyout proposal 'the present IP system is retained for more than $80 \%$ of the global patent-based cash flow of the pharmaceutical companies'.) 
Under these types of arrangements, the technology procurers-who could be governments (such as the EU), intergovernmental organizations (such as WHO, UNDP or the Global Fund), or private foundations-could acquire and make available patent rights for specific medicines for particular geographic markets. ${ }^{248}$ A patent owner could be compensated under a transfer of rights (including pooling) formula, 'which mimics the lost $\mathrm{R} \& \mathrm{D}$ cost recovery from the foregone sales' ${ }^{249}$

$\mathrm{R} \& \mathrm{D}$ cost recovery from developing countries is so low under current projections that buy outs and essential medicines patent pooling arrangements would be extremely cheap compared to other methods of assistance. Once a transfer of rights occurred, and the license was issued, Prof. Outterson contends that competition should 'drive the unit price down towards the actual marginal cost of production' ${ }^{250}$ Lower prices should also discourage the production of counterfeit pharmaceuticals, limiting the incentive to counterfeit drugs in the low- and middle-income countries. ${ }^{251}$

\section{E. Obstacles to obtaining key active ingredients (APIs)}

Much also depends on the ability of potential suppliers to obtain key APIs. The production of these ingredients is increasingly outsourced to firms in certain developing countries, but subject to patent rights and other pressures that effectively reduce their availability to would-be user countries.

This need for APIs, a problem in the best of circumstances, becomes more acute if originator enterprises retaliate against the issuance of compulsory licenses by refusing to register new drugs for market approval. In principle, this form of retaliation leaves affected countries free to obtain the products anywhere or to reverse-engineer them under compulsory licenses (possibly as a remedy for patent abuse) for local production. In practice, the task of reverseengineering can become difficult and costly, and may entail major funding to defray the medicinal chemistry involved. Skills might have to be provided by either existing generic suppliers (in India, Brazil and China) or by a network of universities willing to work in this area. Indeed, Pharma companies may calculate that the costs of reverse-engineering would persuade governments to accept their higher priced offers rather than assume these risks.

The potential difficulties and costs of reverse-engineering needed components of new drugs are increased by possible legal restrictions on research exemptions under the laws where that analysis occurs. ${ }^{252}$ Here much

248 Ibid. The purchasers would then offer 'an open, nonexclusive, no royalty license to any legitimate generic manufacturer, but only for sale in the target markets'. OECD countries would continue to practise normal patent-based pricing.

249 Ibid.

250 Ibid, at 173 .

251 Ibid.

252 For a very restrictive common law approach taken by the Court of Appeals for the Federal Circuit in the United Sates., see Madey v Duke University, 307 F.3d 1351 (Fed. Cir. 2002). 
depends on the exceptions to the patent holder's exclusive rights that may apply in the country where reverse-engineering takes place. Of course, any analysis of this kind conducted in LDCs should be free of patent protection, if the LDC has avoided enacting relevant patent laws under the extension or has moved to disapply its patent laws for medicines under the new dispensation. However, the available skills in these countries remain scarce, unless they were bolstered by transplants from foreign universities and research institutes, or by transplanted generic industries, e.g. Indian generic producers in Bangladesh.

Technical assistance could come from a network of willing universities and research institutes in developed countries, especially if sufficient funds were made available for this purpose. However, the pharmaceutical companies would likely exert pressure on any universities that cooperated in such a venture.

\section{F. Countervailing pressures by industry and governments}

Much depends on the attitudes of OECD governments, especially the United States and the EU. If they support Pharma enterprises and put pressure on developing countries and LDCs, their threats and other measures can divide local governments internally (e.g. Trade Ministry versus Health Ministry) and retard or suffocate efforts to use the TRIPS/ Doha flexibilities and the Amendment to the full. Hopefully, the controversy surrounding Thailand's recent grants of compulsory licenses may eventually establish a new equilibrium more conducive to cooperation rather than confrontation. $^{253}$

It is worth noting that countermeasures taken or threatened by some governments may cross the line of legality under international law. For example, the United States has put both Thailand and Brazil on its priority watch list under Section 301 of the Trade Act. ${ }^{254}$

This approach may conflict with the duties of WTO Members to avoid taking unilateral acts concerning impediments to their expected benefits under the WTO Agreement, as set out in Article 23.1 of the Dispute Settlement Understanding. ${ }^{255}$ Query whether recent actions against both

But, for a liberal statutory approach taken by the US Supreme Court in respect of pharmaceutical research, see Merck v Integra Lifesciences, 125 S. Ct. 2372 (2005).

253 See above nn 141-59 and accompanying text. cf. Kal Raustiala, 'Compliance \& Effectiveness in International Regulatory Cooperation', 32 Case West Reserve J Int'l L 387 (2000); J. H. Reichman, 'The TRIPS Agreement Comes of Age: Conflict or Cooperation with the Developed Countries?', 32 Case Western Res J Int'l L 441 (2000).

${ }^{254}$ See above n 149 and accompanying text.

255 See DSU, Article 23; United States-Sections 301-310 of the Trade Act of 1974, Report of the Panel, WT/DS152/R, 22 December 1999. 
Brazil and Thailand are consistent with these undertakings, not to mention with the Doha Declaration on TRIPS and Public Health.

\section{G. New patent incentives and old market failures}

In a recent article, Maskus and Reichman suggested that the TRIPS Agreement had given rise to 'an incipient transnational system of innovation'. ${ }^{256}$ As developing countries begin to harness some of the potential benefits that system provides, while struggling to contain its social costs, their entrepreneurs may respond positively to the incentive effects that a relatively harmonized, worldwide patent system affords.

\section{Stimulating private REDD investment in poverty-related, tropical or neglected diseases}

In the pharmaceutical sector, developing countries having significant generic production capacities in place, along with a basic infrastructure geared to innovation, may witness a shift to more research-based investments in the future, in place of reverse-engineered substitutes for existing drugs. Some evidence suggests that India is moving in this direction. ${ }^{257}$ Whether researchbased investments in these countries would be directed to poverty-related, tropical or neglected diseases, as one would hope ${ }^{258}$ or to the health problems that define lucrative markets in OECD countries, remains to be seen.

Should private sector investments actually lead to the discovery of new drugs aimed specifically at poverty-related, tropical or neglected diseases, the patent system would have achieved one of its goals, and the market failure currently experienced with regard to public health needs of the South might shrink. If this hypothesis materialized over time, which is certainly a possibility, developing country governments should adjust their public health policies and strategies with a view to encouraging rather dampening such initiatives.

Unlike the situation today, where the major pharmaceutical companies expect to recoup their investments in the OECD countries and developing country markets are relatively incidental to this goal, the hypothetical company that discovers a cure for neglected diseases in the future would have to recoup its costs and make a profit in the poorer markets where the disease was rampant. On this scenario, the need to encourage socially beneficial private investment must be reconciled with short- and long-term public health needs, and caution with respect to compulsory licensing should be in order, lest the incentive to invest be curtailed.

Much would depend on the marketing strategy of the patentee who discovered the cure for a relevant disease. Precisely because it is dealing

${ }^{256}$ Maskus and Reichman, 'Globalization of Private Knowledge Goods', above n 7.

257 See e.g. Janice Mueller, The Tiger Awakens, above n 28.

258 Cf. Henry Grabowski, 'Increasing R\&D Incentives for Neglected Diseases: Lessons from the Orphan Drug Act', in IP and International Public Goods, above n 7, at 457-80. 
with diseases of the poor, the company may voluntarily adopt a marketing strategy based on a high volume of sales and low marginal returns, in order to distribute the drug across the widest possible base of potential patients. ${ }^{259}$ In that event, IPRs in combination with socially desirable marketing strategies would have solved the problem, without government intervention. To the extent some government intervention might still be needed, price controls afford an intermediate option that has proved workable in many OECD countries.

If, instead, a developing country firm that discovered a cure for a widespread Southern disease engaged in the 'low volume, high marginal returns' marketing strategy that big pharmaceutical companies tend to pursue today, it would invite government scrutiny and the possible threat of compulsory licensing along the lines discussed above. In practice, however, one would hope that private-sector pharmaceutical companies dedicated to discovering cures for poverty-related, tropical or neglected diseases would find it in their self interest-both socially and economically- to pursue a strategy based on high volume and low margins. In that event, their financial success, if it materialized, might help persuade the big pharmaceutical companies to adopt similar strategies when marketing their products to poor countries, in which case many of the current problems would be solved.

\section{Changing the marketing model}

From the foregoing analysis, it must be clear that the overall objective of the flexibilities envisioned in Amendment Article 31 bis is not to drive the originator companies out of these markets, nor is it to reduce the incentive effects that stronger patent protection may exert in stimulating $R \& D$ outside the OECD countries. What, instead, the use of TRIPS flexibilities needs to achieve is to persuade Pharma to change its marketing strategy in poor countries from a low volume-high margin approach to a high volume-low margin approach.

In a long-term perspective, moreover, more thought must be given to lessening the private sector's burdens with respect to clinical trial costs, and to the potential advantages likely to accrue from treating these costs as a global public good, whose benefits could also be shared by scientists and researchers worldwide. ${ }^{260}$ While we lack the space to elaborate on this proposal here, it is clear that many of the inequities, hardships and bureaucratic obstacles being imposed on developing countries in order to defray the growing financial burden that clinical trials places on the shoulders of the private sector could be relieved by a more rational reform

\footnotetext{
259 See e.g. the approach of the Drugs for Neglected Diseases initiative (DNDi), described at http://www.dndi.org/.

${ }^{260}$ See generally, Lewis, Reichman and So, above n 216.
} 
based on the recognition that governments are in the best position to provide and regulate essential public goods. ${ }^{261}$

\section{The continuing role of public-private partnerships}

As matters stand, however, we remain a long way from seeing private sector remedies for diseases afflicting poor countries. The existing situation is, instead, characterized by a pronounced market failure, in which diseases of particular relevance to developing countries are significantly underresearched. $^{262}$

Given this market failure, the best immediate hope is the growing success of the Public-Private Partnerships (PPPs) that have been formed to address these diseases. As recently reported, there are now over 60 ongoing research projects sponsored by PPPs, and six or seven new drug registrations are expected in the next five years. However, in many cases private foundations provide the bulk of PPP funding, and contributions from governments remain lower than might be hoped. ${ }^{263}$

Here patents may constitute a barrier to entry unless they are pooled for these purposes, which should be encouraged. Similarly, universities in OECD countries should be encouraged to ensure that government-funded research results are made available to poor countries under humanitarian licenses. ${ }^{264}$ Above all, funds are needed from OECD governments sufficient to ensure that PPP-sponsored research continues at a proper pace. ${ }^{265}$

\section{Strengthening the global scientific foundation}

The existing market failures make it especially important for the public sector to fund research on relevant diseases and, to this end; governments should seek to strengthen the scientific and technical foundations in the affected countries. Here, funds are needed to support local research capacities, especially at universities, and to promote long-term benefits of cooperation with universities in OECD countries, which could strengthen the scientific and technical base in participating poor countries over time. Institutions such as UNESCO, Third World Academies and the US National Academies could assist in this regard, with funds from the United States and the EU. ${ }^{266}$

261 Cf. Drahos, above n 13 at 46-64.

262 See e.g. Sarah Ramsay, 'No closure in sight for the 10/90 health-research gap', 358 Lancet 1348 (2001).

263 See e.g. Nicoletta Dentico, 'DNDi's antimalarial: a new public good for neglected patients, presented at Public Health, Innovation and Intellectual Property Rights: EU Input to the Global Debate, organized by the European Commission Health and Consumer Protection Directorate-General, 2 April 2007. This is not intended to discount the importance of contributions made so far to DNDi by, inter alia, the British and Dutch governments.

264 See e.g. Amy Kapczynski et al., 'Addressing Global Health Inequities: An Open Licensing Approach for University Innovations', 20 Berkeley Tech L J 1031 (2005).

265 See European Parliament 12 July 2007 Resolution, above n 44, to this effect.

266 See European Parliament 12 July 2007 Resolution, above n 44, to this effect. 
Thinking boldly, one might establish a well-funded, peer-reviewed grant making body, modeled on the National Institutes of Health (NIH) in the United States, which would support medical research in and for developing country diseases. This approach might appeal to young scientists in developing countries and provide them with opportunities and outlets for innovative proposals that do not otherwise exist at the present time.

\section{CONCLUSIONS}

Members of the WTO are assessing whether to ratify the Article 31bis Amendment to the TRIPS Agreement. The Amendment embodies a compromise among various stakeholders involved in researching and developing new medicines, manufacturing and distributing them, prescribing and delivering treatment, and those advocating on behalf of patients. The compromise involved government ministries seeking to promote the industrial policy interests of their nationally based producers and government ministries concerned with protecting the public health of their citizens. The process of negotiation was long and difficult, and no stakeholder achieved all of its objectives. From whatever perspective one approaches the Amendment, it is imperfect.

For those whose foremost priority is ensuring access to medicines for the widest number of individuals, the principal questions are (i) whether there is a reasonable prospect of negotiating a less administratively cumbersome solution to the Article 31(f) problem and, if not (ii) whether it would be better to forego the Amendment.

We believe that the most likely outcome of further WTO negotiations on the subject matter of the Amendment would be an impasse. Demands to streamline the administrative process would be met with counter-demands to limit the scope of eligible diseases and country users. As evidence to support this belief, we refer to the aggressive reaction by the EU and United States, and by major multinational pharmaceutical producers, to the recent issuance of compulsory licenses in Brazil and Thailand. The rhetoric of the industrial lobby and supporting governments points strongly in the direction of seeking to limit compulsory licensing to a narrow class of medical conditions and per capita GDP levels.

The world political situation is always changing. A new Executive administration in the United States might endorse a more pro-access policy than the current administration. Recent efforts by the Democratic majority in Congress to rein-in USTR's advocacy of pharmaceutical industry interests point in this direction. Yet the European Commission appears increasingly willing to take on the mantle of pharmaceutical industry champion. And, these are only the primary government actors. Australia, Canada, Japan, Singapore, Switzerland and other high-income WTO Members are also pursuing high IP-protection policies, and any one of these Members might block efforts to 
streamline the Amendment. Moreover, a number of important developing country governments are internally divided on issues of intellectual property protection and access to medicines. Whether the alignment and commitments of developing countries in a new set of negotiations would be the same as those in the earlier negotiations remains to be seen.

We have only a limited basis on which to foresee the results and consequences of IGWG discussions at the WHO. Based on developments so far, with most governments having expressed views in the IGWG process consistent with those expressed in other forums, we deem it unlikely that the WHO process will provide the basis for renewed negotiations on the Amendment at the WTO, though certainly this could happen.

Our judgment is that re-opening negotiations on the Amendment might as likely result in a more restrictive arrangement as a more streamlined one. Meanwhile, the Waiver Decision was expressly designed to remain in effect until it had been accepted by all WTO Members. From this standpoint, there is no compelling reason to press for early ratification of the Amendment. If it does not come into effect in 2007, it can come into effect in 2008, or for that matter, it need not come into effect at all. The Waiver Decision is permanent from a legal standpoint, unless and until the Amendment is accepted by all WTO Members.

In light of the legal status of the Waiver Decision, it can and has been argued that more time should be given for problems to surface before converting it into the 'fixed' form of the Amendment. This is a reasonable argument.

Nevertheless, given the political rhetoric employed by the multinational pharmaceutical industry and supporting governments, we worry that failure to bring the Amendment into force might provide the basis for a concerted campaign to undermine the Waiver Decision's vitality. Delay in ratification would be portrayed by some governments, the multinational pharmaceutical industry and prominent financial media outlets as a rejection of the solution. Government and industry pressure may persuade more economically vulnerable governments not to pursue implementation of the solution in national law, or to be reluctant to use it in practice. We believe these risks argue in favor of a more or less timely ratification of the Amendment, though we accept that reasonable minds can differ about the degree of risk associated with delay, or even failure to ratify.

What matters is that governments implement the Waiver Decision and/or Amendment in national law employing all options for maximum flexibility in its use. We further urge developing country governments to pursue programs of cooperation that will permit them to take advantage of economies of scale in purchasing, as well as in the production and distribution of pharmaceutical products.

The Waiver Decision and Amendment each expressly provide that they are without prejudice to other rights Members may have under the TRIPS 
Agreement. We re-emphasize our view that Article 30 remains a viable option for generic-producer exports of patented pharmaceuticals in circumstances that fall within the terms and context of that Article. The somewhat restrictive approach to interpretation of Article 30 by the panel in the Canada-Generic Pharmaceuticals case ${ }^{267}$ was adopted prior to the Doha Declaration, which placed Article 30 in a new interpretative framework. The WTO Appellate Body has recognized the evolutionary nature of WTO and international law in its Shrimp-Turtles decision and elsewhere. ${ }^{268}$

The OECD governments constantly argue that higher standards of intellectual property protection will encourage 'transfers of technology' to developing countries, which is essential for accelerated progress. But OECD governments suggest that technology transfer occurs through the operation of 'free-market' forces. At least in the pharmaceutical sector, the evidence to support this thesis is not compelling. The major multinational pharmaceutical companies do not 'out-license' newer products for manufacture and distribution by developing country enterprises; research and development is concentrated in the home countries of major producers; and manufacturing facilities are shuttered and relocated as a matter of economic convenience.

The evidence suggests that the wealthy OECD nations are little inclined to promote the development of world-class pharmaceutical producers in poor countries, which might eventually compete with the existing originators. The rhetoric of 'transfer of technology' does not extend to the reality of investment in plant and equipment, upgrading systems for compliance with OECD GMP quality standards, or to the licensing of important pharmaceutical compounds. ${ }^{269}$ There is a great deal of pharmaceutical technology expertise available 'for hire', and pharmaceutical equipment manufacturers are willing sellers. The inhibitions on building up developing country pharmaceutical capacity are mainly financial, although intellectual property issues must and can be addressed if there is a will to do it. We strongly encourage a more proactive role for OECD transfer of technology to the developing country pharmaceutical sector. At the very least, OECD governments should not stand in the way of South-South cooperation.

267 Canada-Patent Protection of Pharmaceutical Products, WT/DS114/R, 17 March 2000.

268 United States-Import Prohibition of Certain Shrimp and Shrimp Products, Report of the Appellate Body, AB-1998-4, WT/DS58/AB/R, 12 October 1998. See also Christine Godt, above $\mathrm{n} 161$, at $227-28$ (stressing power of multilateral consent to control extraterritorial effects), and; Garrison above n 164.

269 See e.g. Claudia Chamas, Developing Innovative Capacity in Brazil to Meet Health Needs, MIHR Study for WHO Commission on Intellectual Property Rights, Innovation and Public Health, WHO Ref. CIPIH Study 10d (DGR), April 2005, at 94; Maria Auxiliadora Oliveira et al., 'Pharmaceutical Patent Protection in Brazil: who is benefiting', in J. Bermudez and M. Oliveira (eds), 2004 Intellectual Property in the Context of the WTO TRIPS Agreement: Challenges for Public Health (FIOCRUZ, ENSP, PAHO 2004), at 161, 172-74. 
The pressing need for more research and development on treatments for poverty-related, tropical and 'neglected diseases' has certainly captured the attention of governments. Today, much of the important work in this area is being done by PPPs, with a substantial portion of the money coming from private foundation donors (such as the Gates Foundation). Creative new structures, such as the Drugs for Neglected Diseases initiative (DNDi), are up and running and it is essential that the scale of government contributions to these efforts be increased.

Whether the flexibilities built into the TRIPS Agreement, including those embodied in the Amendment, will withstand assault from the multinational purveyors of knowledge goods that are driving the WIPO SPLT negotiations and the bilateral and regional FTAs and EPAs remains to be seen. The SPLT negotiations could reduce flexibilities across the board for all countries, while the bilaterals and FTAs have significantly cut back on the ability of national governments to provide public goods that involve intellectual property inputs. The European Commission's decision to follow a more aggressive intellectual property strategy in the EPAs being negotiated with the ACP countries is particularly worrisome in this regard. Some observers, including one of the authors of this report, have gone on record to urge 'a moratorium on further intellectual property standard setting exercises', in order to give the incipient transnational system of innovation, triggered by TRIPS, time to breathe and grow. ${ }^{270}$

At the heart of the intellectual property-access to medicines debate lies the fact that the world community seeks to address a 'public goods' problem with a 'private market' solution. The Doha Declaration recognizes a collective obligation to promote access to medicines 'for all'. ${ }^{271}$ We know that the private market can not meet that goal, and governmental measures are necessary to factor out the income curve when it comes to purchasing medicines necessary to sustain life. Failure to confront this truth results in an endless cycle of conflict, and leaves us with an unresolved collective action problem on a grand scale.

270 Maskus and Reichman, 'Globalization of Private Knowledge Goods', above n 7.

271 See also Thomas Cottier, 'The Doha Waiver', above n 85, at 198 (stressing role of human rights to health and life underlying Doha Waiver and Amendment). 
